AÜIFD Cilt XLIV (2003) Sayı I s. 227-270

\title{
Felsefenin Temel Soruları Bağlamında Orta Öğretimde Felsefe Öğretimi ve Din Kültürü - Ahlâk Bilgisi Öğretimi İlişkisi (Öğretim Programları ve Ders Kitapları Üzerinde Karşılaştırmalı Bir Değerlendirme)
}

\author{
Nurullah ALTAŞ \\ Dr., Ankara Üniversitesi İlahîyat Fakültesi \\ e-mail: altas@divinity.edu.tr
}

Abstract: From the Point View of the Basic Philosophical Questions the Relationship Between Instruction of Religion Culture and Ethics Course and Philosophical Instruction in Secondary Education. Questions which philosophy pointed about ontology, ethics, politics, esthetics, contributes mankind to describe and value their own life or human life. For this reason philosophical education helps pupils achieve their own sense of life by arguing widely these questions. There is a similarity to some extent between philosophical questions and religious questions. Religious beliefs play a major part in answering these questions. Same questions about former disciplines have been taken in to account by instruction of religion culture and ethics course in educational field. In spite of relationship between philosophical and religious education this contact between than isn't taken in to occount. Consequently philosophical education is to take place in conformity with the goals of religious education, since philosophical 
questions display a tendency to distance religious education from it's goals. But answers of these questions must be corresponded to each other. Nevertheless religious education sometimes does not take in to account this correspondence. This approach arises conceptional conflicts.

Key Words: Religious Education, Philosophical Education, Instruction, Philosophical Questions, Sense of Life, Ethics Course

\section{A. Giriş}

\section{Problem}

Din, kendine has özellikleri sebebiyle bir çok bilimin üzerinde ortaklaşa çalıştığı bir alandır. Başta sosyoloji olmak üzere, psikoloji, pedagoji ve felsefe gibi bilimler, din olgusunu farklı yönlerden araştırma konusu yaparlar. Dinî bu şekilde farklı bilimlerin araştırmalarında ilginç hâle getiren neden; onun farklı boyutlar içermesi ve bu boyutların değişik disiplinlerin alanlarıyla kesişiyor olmasıdır.

Dolayısıyla dinîn öğretiminden söz ettiğimiz zaman da farklı bilimlerin üzerinde yoğunlaştığı bir disiplin gündeme geliyor demektir. Nitekim Cemal Tosun, din eğitimi biliminin disiplinlerarası niteliğini tartışırken hem İlahîyat bilimlerinin hem de diğer din ve insan bilimlerinin verilerini, gerektiği kadarıyla, kendi metotlarıyla, kendi amaçları doğrultusunda kullanabileceğini belirlemekte ve şunları eklemektedir:

"Din eğitimi bilimi, sadece alıcı konumunda bir disiplin gibi de görülmemelidir. İlişside bulunduğu bilimler de onun verilerini kullanmak durumundadır. Özellikle İlahîyat bilimleri din eğitimi bilimi için, din eğitimi biliminin toplumsal açıdan gerekli gördüğü bilgi ve yorumları üretecek, din eğitimi bilimi ise bunlanı ögretime müsait hâle getirmeye çalışacaktır."

İlk ve ortaöğretim programları her ne kadar uygulamada birbirinden bağımsız dersler altında düzenlenmiş olsa da bu derslerin bir kısmı aslında birbirleriyle sıkı ilişki içindedir. Örneğin tarihle ilgili bir çok konunun anlaşılması için edebiyat, coğrafya, sosyoloji, felsefe ve din öğretiminin desteğine ihtiyaç bulunmaktadır. Farklı olarak din öğretimini merkeze alarak düşündüğümüzde de bu alanın etkinliğinin edebiyat, tarih ve felsefe gibi alanların desteğine bağlı olduğu görülmektedir. Bütünlük içinde bir kültürün anlaşılması, disiplinler arası bir yaklaşımla düzenlenmiş programlarla mümkün olabilmektedir. Eğitim bilimcileri, bu anlayışa zıt bir şekilde "bölünmeci" bir anlayışla hazırlanan programlarda her bir konu ve dersin diğerleriyle çok az ilişkiye geçtiğinden bu derslerin kendi başlarına birer ada gibi kaldığını savunmakta ve bunun sonucunda da öğrencilerin bütünü anlamada oldukça zorlandıklarını iddia etmektedirler. Bu eğitimbilimcilerden Gerald Graff'a göre her bir ders, dinîn de kendine özgü cevaplar verdiği alanlara girdiği zaman bu konuda en azından dinî alternatiflerin de

' Cemal Tosun, Din Eğitimi Bilimine Giriş, Pegem-A Yayıncılık, Ankara 2001.63. 
bulunduğunu doğrulamalı ve öğrencileri konu üzerinde tartışmalar yapmaya teşvik edebilmelidir. Graff, tüm derslerin birer din dersine dönüştürülmesini önermediğini söylemekte ve bu derslerin doğası gereği seküler yapılarını kabul etmekle birlikte, öğrencilerin seküler anlayış çerçevesinde doktrine edilmesine karşı olduğunu vurgulayarak işlenen konuların tartışmalı yapısının ögrencilere fark ettirilmesi gerekliliğine dikkat çekmektedir ${ }^{2}$.

Felsefe öğretimi, amaçları ve muhtevası itibarıyla din öğretimi ile en fazla ilişkide bulunan alandır. Bilgi, bilim, varlık, ahlâk, estetik, siyaset ve din felsefesi gibi felsefe disiplinleri, ortaya konan cevapları tartışırken dinlerin yaklaşımlarına da içeriğinde yer verir. Din öğretimi de felsefe öğretimi içinde ortaya konan dinî perspektifi yansıtan cevaplardan yaşam içinde uygulanan ve uygulanabilir olanların tartışılmasını sağlar. Değişik felsefî akımlar ve ideolojiler, insanın varlı̆̆ı, geleceği ve mutluluğu ile ilgili değişik yorumlar getirirken, dinîn de getirdiği yorum bir imkân olarak onların yanında yer alabilir ${ }^{3}$. Çünkü din öğretiminin amaçlarından birisi de insanın hayatı anlamlandırma çabalarına yardımcı olmaktır. Beyza Bilgin'in ifadesiyle din eğitimi, hayatın anlamını aramaya çağıracak ve bu arayışı canlı tutacak, onun sürekliliğini sağlayacaktır ${ }^{4}$.

Felsefenin bu önemi nedeniyle din öğretimini felsefeyi merkeze alarak gerçekleştirme şeklinde özetlenebilecek yeni bir yöntemi okullarında uygulayan Norveçli din eğitimcisi Beate Borresen, felsefe-din ögretimi ilişkisini bir adım ileri götürerek "felsefe, din öğretiminin bir dalı olmalı mıdır?" tartışmasını açar ve şunları söyler:

"Hem evet, hem de hayır! Evet; çünkü felsefe, bir okulda, bütün derslerin bir parçası olmalıdır ve bir metot olarak ele alınmalıdır. Çünkü filozoflar dinlerle ilgili pek çok soruya cevaplar bulmaya çalışmaktadırlar ve de ahlâk bilimi, felsefenin bir alt disiplinidir. Hayır; çünkü felsefe diğer derslerin sadece bir dalı veya metodu olursa, gerçeği kayıtsız ve şartsız olarak araştırma konusundaki özelliğini kaybedebilir. Mesele sadece sorunları çözmek değildir, aynı zamanda felsefî ve demokratik özellikler ve alışkanlıklar geliştiren yeni bir yönteme başlamaktır... Felsefe, çocuklara farklı dinler ve gelenekler arasındaki diyaloglarda ve toplantılarda önemli olan davranışları olumlu yönde geliştirmek amacıyla yardımcı olabilir. Bir çok cevabın bulunduğu bu dünyada hoşgörü ile eleştirel düşünceyi birleştirmek gerekir..."

2 Gerald Graff, Beyond the Culture Wars'dan nakleden Warren A. Nord, Religion and American Education, The University of North Carolina Pres, 1995, 200.

${ }^{3}$ Mualla Selçuk, "Din Öğretimi Özgürleştiren Bir Süreç Olabilir mi?”, Islamiyat, C.1, sayı 1, 75.

4 Beyza Bilgin, Eğitim Bilimi ve Din Eğitimi, Yeni Çizgi Yayınlan, Ankara 1996, 45.

5 Beate Borresen, "Sorgulayıcı Metot: Din Öğretimine Norveç Yaklaşımı", Din Öğretiminde Yeni Yaklaşınılar Sempozyumu, Çev: Şehbal M. Gökdal, Milli Eğitim Bakanlığı Yayınıan, İstanbul 2003. 
Ancak bu karşılıklı ilişkiye rağmen her iki öğretim alanının da birbirinden yeterince yararlandığını söylemek mümkün değildir. Bu araştırmamızda bizim cevap arayacağımız temel sorun şu şekilde ifade edilebilir: "Felsefe ögretimi ve din öğretimi arasında iliş̧i kurulmasınt gerektiren alanlar hangileridir ve bu iki ögretim alanının pratik öğretim uygulamalarında birbirlerinden nasıl yararlanması gerekir?"

\section{Araştırmanın Amacı ve Önemi}

Talim Terbiye Kurulunun 26.06.1992 tarihînde uygulamaya karar verdiği Felsefe ders programında, genel açıklamalar başlığı altında programın temel özellikleri hakkında bilgi verilirken, belli bir problemin değişik felsefe alanları (bilgi, bilim, varlık, estetik, siyaset ve din gibi)'nda ele alını̧ biçimlerinin göz önünde bulundurulduğu ve böylece felsefî düşünce tarzının kazandırılmasının amaçlandığı ortaya konmaktadır. Nitekim İonna Kuçuradi, felsefe ögretiminin kişilere, insanın çeşitli olanaklarının farkh değerini gösterdiğini, bu bilgilerin ışı̆̆ında kendilerini görebilmelerine imkân tanıdığını, kendi olanaklarını görebilme ve geliştirebilmelerine, temel amaçlarını; oluşturmalarına, yaşamdan ne istediklerini belirlemelerine ve kendi yolların çizebilmelerine yardımcı olan bir eğitim alanı olduğunu söyler.

Felsefenin yeri ve öneminin yanı sıra din, sanat ve kültür gibi diğer etkinlik alanlarıyla benzeyen veya ayrılan özelliklerinin verilmesi de bu programda amaçlanmaktadır. Yine genel açıklamalar başlığı altında felsefenin kendisinden, tarihînden ve filozoflarından söz ederken Farabî ve Gazalî gibi Türk-İ̀sâm düşünürlerinden bahsedilmesi ve bunların konuyla ilgili görüşleri uygun yerlerde uygun ölçülerde dile getirilerek; Türk insanının ait olduğu kültür dünyasının felsefî başarılarının evrensel felsefe hareketi içindeki yerini ve değerini belirtme imkânı getirildiği açıklanmaktadir.

Felsefe derslerinin amaçları içinde ise; bilgi kuramı, varlık felsefesi, ahlâk felsefesi ve din felsefesi gibi alanlarda kavramlar ve alanla ilgili temel bilgilerin kazandırılmasının amaçlandığı belirtilmiştir. Felsefenin hayatın anlamlandırılması sürecindeki katkıları ve bu katkıların orta öğretim düzeyinde konu edilmesi aşamasında dinîn varlık alanıyla kesişim içine girmektedir ${ }^{7}$. Felsefenin sorguladığ 1 ve kendine özgü yöntemleriyle araştırma alanına soktuğu konulardan önemli bölümü, dinîn/dinlerin kendi bakış açılarıyla cevaplandırdığı sorularla doludur. Felsefe derslerinin amaçlarında somutlaşan ve bu amaçlar çerçevesinde bağımsız üniteler şeklinde düzenlenen "Felsefenin Anlamı ve Çeşitli Ünitelerle İlişkisi",

" İonna Kuçuradi, "Açı̧ Konuşması, Felsefe Açısından Eğitim ve Türkiye'de Eğitim", Seminer Bildirileri 17-18 Kasım 1995, Türkiye Felsefe Kurumu, Ankara 1996, 10.

? Bkz. Adem Akıncı, Hayata Anlam Vermeye Din Öğretiminin Katkıst, Yayımlanmamı Doktora Tezi, AÜSBE, Ankara 2002. 
"Bilgi Felsefesi", "Bilim Felsefesi", "Varlık Felsefesi”, "Ahlâk Felsefesi" ve "Din Felsefesi" başlıkları altında yer alan sorulara bilinen ilk filozofların verdiği cevaplardan önce, yeryüzündeki farklı dinlerin vermiş olduğu cevaplar bulunmaktadır. Dinlerin vermiş olduğu bu cevaplar, felsefenin sistematize oluş sürecine paralel olarak düzenlenmiş ve İlahîyatçlar bu soruların cevaplarını derinliğine inceleyerek ortaya koymaya çalışmışlardır.

Okullarda dinîn öğretime konu edilmesi oldukça tartışmalı bir sorundur. Geleneksel eğitim modelimizde dinîn merkezde yer almasına karşın, dinîn diğer dersler gibi bağımsız bir öğretim alanına dönüştüğü Batı tarzı bir eğitim modeli oluşturmaya yönelik değişikliklerde sorunlar yaşanmaya başlamıştır. Dinle ilgili tüm soruları çözdüğüne inanan geleneksel ilmihalci anlayış, genel eğitimin içine monte edilmiştir. Böylelikle sorgulayıcı ve eleştirel bilim anlayışı temelinde gelişen diğer alanların aksine din alanında çoğulcu dinî anlayışlar içindeki belirli bir söylemin tek taraflı ve eleştirisiz kabulü ön görülmüştür. Din dersleri, genel öğretim içindeki bu başlangıç anlayışında kalmayıp, yöntemleri, içeriği ve bakış açılarında açılımlar sağlamasına rağmen, diğer alanlarla zaman zaman çatışmalar yaşamaya da devam etmiştir ${ }^{8}$.

Din öğretiminin bu çatışmaları en yoğun yaşadığı alanlardan birisi de felsefedir. Felsefe derslerinin amaçları ve hedef davranışları incelendiği zaman dinîn var oluş sebebi olan hayatî soruların aynı zamanda felsefenin de merkezinde yer aldığı gözlemlenmektedir. Bu kesişime rağmen şimdiye kadar Türk Milli Eğitimi çerçcvesinde felsefe ögretimi ve din öğretimi ilişkisi ciddî bir şekilde sorgulanmış değildir. Türk Milli Eğitim sisteminde Felsefe öğretiminin üzerinde dinîn, din öğretiminin üzerinde de felsefenin etkisinin ortaya konduğu bir bilimsel çahışmaya rastlayamadım. Bu tür bilimsel çalışmaların bulunmaması, iki öğretim alanının birbirlerinden yeterince yararlanmalarına engel olmuş ve birbirlerinden kopuk ilerlemelerine sebep olmuştur. İki öğretim alanındaki ilişkinin ve uygulamadaki kopuklukların ortaya konması, öğrencilerin hayatı anlamlandırmada en önemli verileri aldıkları felsefe ve din alanlarından en üst düzeyde yararlanmalarını sağlayacaktır.

\section{Araştırmanın Hipotezleri (Denenceler)}

Felsefenin sorularına dinîn verdiği cevaplar bağlamında din öğretimifelsefe ögretimi ilişkisi aşağıdaki hipotezler çerçevesinde çözümlenmeye çalışılacaktır:

1. Felsefenin temel sorularına, geçmişten günümüze dünyanın çeşitli bölgelerindeki farklı dinlerde de cevap arama çabası içinde bulunmuşlardır.

2. Felsefe öğretimi ile Din Öğretimi benzer soruların cevapları ile meşgul olduğundan birbirleriyle ilişki içindedir.

8 Geniş bilgi için bkz. Nurullah Altaş, "Türkiye'de Örgün Öğretimde Dinin Yeri”, Marife Dergisi, Y11 2, sayı 1, Bahar 2002, 219-229. 
3. Bu iki öğretim alanı, birbirleriyle ilişki içinde olduğu hâlde Türkiye'deki uygulamada birbirlerinden yeterince yararlanmamışlardır.

4. Liselerdeki DKAB program ve ders kitapları felsefenin tartıştığı sorulara dinlerin verdiği cevaplar konusunda yeterince yardım edici nitelikte değildir.

5. Felsefe öğretimi ve din öğretiminin birbirleriyle kopukluğu, öğrencilerin hayatı anlamlandırma çabalarında olumsuz rol oynamakta ve çatışmalar yaşamalarına sebep olmaktadır.

\section{Araştırmanın Yöntemi}

Yukarda belirlemiş olduğumuz hipotezlerin ilk dördünün test edilmesinde literatür taramasıyla birlikte felsefe programları ve Milli Eğitim Yayınları içinde olan Liseler için bir Felsefe ders kitabı ile lise DKAB programları ve Milli Eğitim Yayınları ve özel yayınevlerinden felsefenin sorularını içeren tesadüfi örneklem yoluyla seçilmiş üç ders kitabının karşılaştırılması sonucu elde edilen verilerden yararlanılmıştır.

Beşinci hipotezin test edilmesinde ise Bingöl ilinde farkhı liselerde felsefe dersi almış lise son sınıf veya mezun durumdaki 100 öğrenci üzerinde uygulanan yarı yapılandırılmış görüş̧me yöntemine göre hazırlanan ölçme aracından elde edilen verilerden yararlanılmıştır. Bunlarla birlikte tüm hipotezlerin test edilmesinde Üniversiteye hazırlık amacıyla bir dershaneye devam eden altı gruba dağılmış 180 ögrenciyle felsefe dersleri kapsamında yapılan tartışmalar, bire bir görüşmeler ve gözlemlerden de yararlanılmıştır.

Yapılan görüşmeler ve yukarda özellikleri verilen grup üzerinde yapılan gözlemlerden elde edilen bulguların, sadece Bingöl iliyle sınırlı olduğundan genellemeler yapmak için yeterli olmadığını kabul etmekle birlikte bu alanda yapılacak geniş kapsamlı çalışmalara rehberlik edecek nitelikte olduğunu düşünmekteyim.

\section{B. Felsefenin Temel Soruları ve Liselerde Felsefe Öğretiminin Amaçları}

Felsefenin soruları, problemleri ve çözüm denemeleri, insanın doğal yaşamına dayanırlar. Bu yüzden yaşamdan kopuk olduğu iddia edilen soyut felsefî anlayışlar bile en sonunda ve daima insan yaşamına ait bir fenomen olarak kendinî gösterir. Felsefe soruları ve felsefe problemlerine her dönemde yeni soru ve problemler eklenir; bu soru ve problemlere yine her dönemde benzer veya değişik çözüm denemeleri üretilir. Bu bakımdan felsefenin soruları aynı oldugu hâlde, tavırlar ve yöntemler farklıdır. Ne

"Yarı Yapılandırılmış Görüşme (Nicel-Nitel Görüşme): Bir yandan standartlaşmayı sağlamak, öte yandan görüş derinliğine ulaşmak üzere standart bir cetvel kullanılmakla birlikte görüşmeciye de esneklik sağlayan bir görüşme modeli. Geniş bilgi için bakınız: Muzaffer Sencer-Yakut Irmak, Toplumbilimlerinde Yöntem, Say Yayıncılık, İstanbul 1984. 147. 
kadar felsefeci varsa o kadar felsefe vardır denebilir ${ }^{10}$. Felsefe bir bakıma sorulara ve problemlere getirilen yanıtlar ve çözüm denemeleri, bu yanıt ve çözüm denemelerinin yol açtığı yeni soru ve problemler topluluğudur ${ }^{11}$.

Liselerde 1992 yilından itibaren uygulamaya konan Felsefe Dersi programında felsefe dersleriyle, belli bir problemin değişik felsefe alanlarında (bilgi, bilim, varlık, etik, estetik, siyaset ve din gibi) ele alınış biçimlerinin göz önünde bulundurulduğu ve böylece temel amacın öğrenciye felsefî düşünme tarzının kazandırılması olduğu belirlenmektedir ${ }^{12}$. Felsefe derslerinin, felsefenin yeri ve öneminin yanı sıra felsefenin din, sanat ve kültür gibi diğer etkinlik alanları ile benzeyen ve ayrılan özellikleri de ortaya koyacağı vurgulanmaktadır. Programın "Genel Açıklamalar" başlığı altında, bu derslerin bir yandan bilgi, bilim, bilimsel yöntem, bilimsel araştırma ve çeşitli bilimler hakkında genel ve sistemli bilgiler verirken, öte yandan insanın varlı̆̆ının ve onun ifadesi olan kültürün yalnızca bilimsel bilgi üzerinde oluşmadı̆̆ı, insanın ayn zamanda pratik, ahlâkî, politik, estetik ve dinsel bir varlik olduğunu belirtmek, bu alanlara ilişkin felsefí tutum ve yaklaşımları tanıtmak; böylece gerek insan gerekse kültür hakkında daha geniş, daha zengin bir anlayışın oluşturulmasını hedeflediği ortaya konmaktadir $^{13}$.

Felsefe dersinin amaçları ortaya konurken de diğer alanlarla ilişkisini kavrayabilme, doğru-evrensel-zorunlu bilginin imkânını kabul eden görüşleri kavrayabilme, varlık felsefesinin konusunu kavrayabilme, varlık problemleri ile ilgili temel yaklaşımları kavrayabilme, ahlâk felsefesinin konusunu kavrayabilme, evrensel bir ahlâk yasasının olup olmadığını kavrayabilme, din felsefesinin konusunu kavrayabilme ve Tanrı'nın varlığına ilişkin farklı yaklaşımları kavrayabilme gibi amaçlarla dinîn de alanı içinde bulunan kavramsal içeriğe geçiş yapılmaktadır. Şimdi üniteler bazında temel felsefe sorularının dinle ilişkisini ortaya koymaya çalışacağız.

\section{Felsefeye Giriş}

"Felsefeye Giriş" ünitesi içinde "Bilgi Türleri" alt başlı̆̆ı altında dinsel bilgi ve felsefenin çeşitli alanlarla ilişkisi başlı̆̆ı altında felsefe-din ilişkisi konu edilmektedir.

Bu ünite altında amaçlar-davranışlar belirlenirken "felsefenin konusunu kavrayabilme" amacının altında dinsel bilgi, sanat bilgisi ve teknik bilginin özelliklerini ve farklı yönlerini karşılaştırmalı olarak özetleyebilme davranış olarak ortaya konmaktadır. Felsefenin diğer alanlarla ilişkisini kavrayabilme amacı altında ise felsefenin dinle ilişkisini açıklayabilme becerisinin

11) İhsan Turgut, Felsefenin Temel Sorunlar, Izmir 1991, 5.

"Alwin Demer, Felsefe, Günümüzde Felsefe Disiplinleri, Editör ve Çeviri: Doğan Özlem, Ara Yayıncilik, 11.

${ }^{12}$ Felsefe Dersi Programi (11. Sinıf), 716.

${ }^{13}$ Agy. 
kazandırılması, hedeflenen davranış olarak belirlenmiştir. Programda bu ünite altında işlenişle ilgili bilgiler verilirken dinle ilgili olarak yukarıdaki davranışlara iliş̧in bir açıklama yer almamışıı ${ }^{14}$.

$\mathrm{Bu}$ ünitenin işlenişini ders kitabında incelediğimiz zaman ise dinsel bilgi ile ilgili şu bilgilerin yer aldığını gözlemlemekteyiz:

"Dinsel bilgi, bilgi aktı inançla kurulan bir bilgidir. Bu bilgi, tanrı ile inanan arasında bir inanç bağı olması bakımından öznel (sübjektif)tir. İnsandaki mutlak bir güce inanma ve sığınma ihtiyacı, nedenini bilmediği ve korktuğu doğal olaylar karşısında tapınma eylemini meydana getirmiştir. Dinsel bilgi, değişme ve aklın eleştirisine kapalı, yani mutlaktır. Örneğin öldükten sonra yeniden dirileceğine inanma, bir dinsel bilgidir."15

Burada dinsel bilgiye ilişkin olarak verilen bilgilerde oldukça iddiah genellemeler bulunmasına rağmen örnek sadece inançlar hakkında verilmektedir. Halbuki dinsel bilgi üzerine her bir din bağlamında ayrı ayrı tartışmalar yapılırken, özellikle İslâm düşünürleri inanç ve ritüeller konusunda bile birbirinden oldukça farklı zeminlerde yoğun tartışmalar yapmışlardır.

Necati Öner, dinsel bilgiye ders kitabındaki homojen yaklaşımdan farklı bir şekilde yaklaşarak dinsel bilginin iki yönüne dikkat çeker. Öner'e göre dinsel bilginin birinci yörn̈üü vahiyle gelen bilgiler oluşturmaktadır. Bilginin özü, aşkın bir varlık tarafından insana bildirilmiştir. Bu sebeple değişmez ve mutlak doğru olarak kabul edilir. Dinîn temelinde mutlak olarak kabul edilen bilgiler bulunur. Bu durum kitabî olmayan dinler için de geçerlidir, mesela Buda'nın koyduğu ilkeler için de aynı durum söz konusudur. Öner, dinlerde Allah'ın mutlak bilgisinin yanında, insan eseri olan bilgiler de bulunduğunu söylemektedir. Bunlar da dinsel bilginin ikinci yönünü oluşturmaktadır ve Allah bilgisinin yorumlarıdır. Dinlerde farklı mezhep ve tarikatların bulunuşunun sebebi, aynı konuda farklı fikirlerin bulunmasıdır. Bu farklılı Allah'ın bilgisinin farklı yorumlanmasından kaynaklanır. Bu sebeple bir dinde, Allah'ın bilgisine dayanan farklı uygulamalar görüilmektedir. Öner devam ederek farklılıkların dindeki insana ait bilgilerden meydana geldiğini iddia eder. Bundan dolayı da İslâm medeniyetindeki tefsir, hadis, fıkıh, kelam gibi ilimler insan eseri olan bilgileri içermektedir ve bu bilgilerin doğruluğu veya yanlışlığı tartışılabilir ${ }^{16}$.

Bu anlamda İslâm bilim geleneğinde eleştirel kimliğin giderek yaygınlaştığını ve bu niteliğe dayalı olarak bir çok düşünce akımının ortaya çıktı̆̆ını söylemek gerekmektedir. Nitekim Necati Öner, bilgiye dayalı tüm etkinliklerde çoğulculuğun insanlığın kaçınılmaz kaderi olduğuna vurgu

\footnotetext{
14 Felsefe Dersi Programı, 718-719.

is Atilla Çelik-Aysel Bal, Liseler Için Felsefe Ders Kitabı, MEB Yayınlanı, İstanbul 1999, 11.

${ }^{16}$ Necati Öner, Felsefe Yolunda Düşünceler, Akçağ Yayınlan, Ankara 1999, 209-210.
} 
yapmaktadır ${ }^{17}$. DKAB derslerinin de bu konulara programları içinde yer açması bir zorunluluk olduğu gibi, felsefe kitaplarındaki içeriğin de yanlış anlamalara sebep olacak tek yanlı açıklamalardan kurtarılması gerekmektedir.

Felsefe-din ilişkisi ise ders kitabında şöyle anlatılmaktadır:

"Kültür tarihî bakımından din ve mitoloji felsefeden önce gelir. Din ve mitolojideki temelsiz ve yetersiz açıklamalar felsefenin doğuşunda önemli etkenlerden birisidir... Her ikisi de varlığı ve yaşamı bütünselliği içinde açıklamaya çalışır. Amaç ve yöneliş bakımından benzerlikleri vardır; varlığın ilk nedenlerine yönelir ve belirlemeler yaparlar. Örneğin, evrenin kaynağı nedir? sorusunu hem din ve hem de felsefe, bütünselliği içinde anlamaya çalışır. Dinsel bilgiler "inanca” dayalıdır. Kaynağı ilahîdir. Örneğin tek tanrılı dinlerde vahiy yoluyla iletilmiştir. İnsan, dinsel bilgilere akıl ve mantık yoluyla ulaşamaz. Din, mutlak ve ilahî varlığın iletileridir. Mutlaktır, sorgulanmaz, inanılır. Değişime ve eleştiriye kapalıdır."18

Burada yapmış olduğumuz alıntılarda da görüleceği gibi İslâm dinî temel alındığında ders kitabı bir çok yönden eleştiri konusu olabilecek saptamalarda bulunmaktadır. Öte yandan yine felsefî bir bakış açısıyla yaklaştığımızda, felsefenin en önemli özelliklerinden birinin baskı yapmaması, düşüncelerini zorla kabul ettirmemesi, kesin tanımlardan ve tek boyutlu çözümlemelerden kaçınması olduğunu görürüz $z^{19}$. Halbuki yazarların burada yapmış olduğu, din-felsefe ilişkisini muhtemelen Hristiyan Kültürü-felsefe arasındaki tarihsel ilişki bağlamında çözümlemekten ibarettir. Bu da tek boyulu bir çözümlemedir ve genelleme yaptığınız zaman hatalı düşünceler ortaya çıkmasına neden olmaktadır.

\section{Bilgi ve Bilim Felsefesi}

Felsefe programında "Bilgi Felsefesi" ünitesi altında direkt dinle ilişkili olarak bir başlık yer almamaktadır. Ancak "bilgi kuramının temel problemi (doğru bilginin imkânı problemi)ni kavrayabilme" amacı altında mümkün olduğunu savununlar veya mümkün olmadığını savunanların yaptıkları tartışmalarda İslâm düşünürlerinin görüşlerine hem programlarda ve hem de ders kitaplarında yer verilmemiştir. Örneğin felsefe dünyasında yapmış olduğu eleştirilerle haklı bir üne sahip olan Gazzalî'nin bu konu ile ilgili görüşlerinden bahsedilmemektedir. Her iki anlayış savunucuları arasında da günümüz İslâm dünyasını ve Türkiye'yi etkileyen bir çok düşünce akımı bulunmaktadır ve bu konuda yapılan tartışmalar, günümüz dünyasında

17 Öner, 212.

${ }^{18}$ Çelik-Bal, 16-17.

${ }_{19}$ Necla Arat, Ideolojik Bağlamda Din-Bilim-Felsefe, Cumhuriyet Döneminde Türkiye'de Öğretion ve Araşırma Alanı Olarak Felsefe, Ed. Betül Çotuksen, Türkiye Felsefe Kurumu, Ankara $2001,153$. 
sosyal veya siyasal hayatın şekillenmesinde etkin olabilmektedir ${ }^{20}$. Bu etkinlik sebebiyle de aynı tartışmaların belli ölçülerde Din Kültürü ve Ahlâk Bilgisi derslerinde de yansitılmalıdır.

Bilim tarihî içinde İslâm'ın bilim anlayışının teşvik edici karakterinin önemli karşılıkları bulunmaktadır. İslâm dünyasında tarihîn çeşitli dönemlerinde evrensel bilim sürecine değerli katkılar sağlamış bir çok bilim adamı vardır. Gazzalî, İbni Sina, İbn Rüşd, Harezmî, Ömer b. Hayyam, Birunî vs. bir çırpıda adları aklımıza gelenlerdir. Bu katkıların ardında İslâm'ın kendine özgü katkılarıyla şekillenmiş özgün bir metodolojinin bulunduğu inkâr edilemez. Ancak Müslümanların bilime katkıları araştırılırken özgün metodolojileri çok fazla ön plana çıkarılmamaktadır.

Günümüzde çağdaş bilim anlayışlarının, bilimin sonuçları itibarıyla insanoğlunun karşısına çıkarmış olduğu sorunlarla başa çıkabilmek amacıyla giriştikleri metodoloji arayışlarında Müslüman bilim adamlarının bakı̧̧ açılarını da göz önüne almak önemli açılımlar sağlayabilecektir.

\section{Varlık Felsefesi}

Varlık felsefesi (ontoloji) başlıklı ünitede "varlık felsefesinin konusunu kavrayabilme" amacı altında verilen davranış, direkt olarak dinîn alanına girmekte ve felsefe kitapları içeriğinde ise sorular cevapsız bırakılmaktadır. Programda bu konuyla ilgili davranış şöyle ifade edilmiştir:

“Metafiziğin varlıkla ilgili temel soruları (Varlık var mıdır? Varlı̆̆ın kökeni nedir? Varlık değişken midir? Varlığın ana maddesi nedir? Varlık bir midir, çok mudur? Evrende düzen var mıdır? Evrende özgürlük var mıdır? Evren sonlu mudur, sonsuz mudur? Evrende gayecilik var midir?)'nı sıralama."

Nitekim ders kitabında da hedef davranı̧ istikametinde metafiziğin varlıkla ilgili temel soruları sadece sıralanmış; cevaplara ilişkin tartışmalarla ilgili öğrencilerin fikir edinebilecekleri bilgilere yer verilmemiştir. Cevaplarıyla dinîn yoğun olarak meşgul olduğu ve ders kitabında cevapsız olarak sıralanan sorular şunlardır:

- Varlık nedir?

- Varlık var mıdır?

- Varlığın temeli nedir?

- İnsanın bu dünyadaki yeri nedir?

- Evrende bir düzen var mıdır? Düzen varsa bunu belirleyen nedir?

- Ruh var midir? Ruh bedenin bir fonksiyonu mudur?

20 Islâm'ın bilgi konusunudaki yaklaşımı ve İslâm düşünürlerinin bu konudaki tartışmaları için bkz. Necip Taylan, Gazzalî'nin Düşunce Sisteminin Temelleri, IFAV Yayınları, Istanbul 1989; Hüseyin Atay, "Kur'an'da Bilgi Teorisi”, AÜIF Dergisi, c. XVI; Alparslan Açıkgenç, Bilgi Felsefesi, İnsan Yayınları, İstanbul 1992; İsmail R. Faruki, Bilginin Islamileştirilmesi, Çev. Fehmi Koru, Risale Yayınları, Istanbul 1985; Fazlur Rahman, İslam ve Çăgdaşlık, Fecr Yayınlanı, Ankara 1990. 
Ders kitabında pozitivist felsefenin metafiziğe (varlıkla ilgili bu sorulara) karşı çıktığı, Kant'ın ise metafiziği kabul ettiği ancak bilinemeyeceğini savunduğu görüşlerine yer verilmektedir. Bu soruların cevaplarına ilişkin olarak dinîn de katıldığı tartışmalara felsefe programı içinde kısmen de olsa yer verilmesi gerekirken, din öğretimi çerçevesinde ise derinliğine işlenmesi gerekmektedir. Öğrencilerin, din öğretimi çerçevesinde ontoloji üzerinde yapılan tartışmalardan İslâm dinî belirleyiciliği ekseninde haberdar olması ve diğer dinlerin bakış açılarıyla karşılaştırmalar yapabilecek derecede bilgi sahibi olması zorunluluktur.

Programda bu ünitenin işlenişi ile ilgili bilgiler verilirken varlık sorununun felsefe ile başladığı iddiasının örneklerle içeriğe dâhil edilmesi gerektiği belirtilmekte ve tarihî süreç içinde bu konunun felsefe ve bilim d1şında hiç bir alan tarafından sorgulanmadığı gibi bir izlenim bırakılmaktadır. Ünite çerçevesinde açılımların yapılması gereken kavramlardan dinîn de alanına giren oluş, var oluş, ideal varlık, mümkün varlık, zorunlu varlık gibi kavramlara ilişkin olarak ders kitabında farklı görüşler yeterli bir şekilde yer almamış, dinî tabanlı olanlara ise hiç yer verilmemiştir. Bu boşluğun DKAB dersleriyle giderilmesi, öğrencilerin kavramlara ilişkin geniş bir bakış açısına sahip olmalarını sağlayacaktır ${ }^{21}$.

\section{Ahlâk Felsefesi}

Ahlâk, neredeyse tüm dinlerin yoğun olarak ilgilendiği ortak bir konudur. Lise felsefe ders programında bu ünite altında ahlâk felsefesinin temel kavramları, temel sorular, kişi vicdanı karşısında evrensel ahlâk yasasının olup olmadığı, evrensel ahlâk yasasını belirleyen özellikler dinlerin de kendilerine özgü yöntemlerle cevaplar geliştirdiği alanlardandır.

"Ahlâk felsefesinin konusunu kavrayabilme" amacının altında etikle ilgili temel kavramlar (iyi-kötü, özgürlük, erdem, sorumluluk, vicdan, ahlâk yasası, ahlâkî karar, ahlâkî eylem)ı örneklerle açıklama davranış olarak belirlenmiştir. Yine "insan ahlâkî eylemlerde bulunurken gerçekten özgür müdür? Kişi vicdanı karşısında evrensel ahlâk yasası var mıdır? Ahlâk yargısının niteliği nedir? gibi soruların ahlâk felsefesinin temel soruları olduğunu açıklama" davranıs olarak belirlenmiştir. Bu soruların cevaplarını verebilme de davranışlar arasında sayılmıştır. Ahlâkî eylem açısından özgürlük-sorumluluk ilişkisinin açıklanması, ahlâk yasalarının diğer yargı türlerinden farkını yorumlama da ahlâk felsefesinin konusunu kavrayabilme amacının altındaki hedef davranışlar arasına alınmıştır.

Bu ünite içindeki diğer bir amaç, evrensel ahlâk yasasının olup olmadığını kavrayabilmedir. Bu amaç altındaki davranışlardan dinîn de alanına girenler aşağıda sıralanmıştır.

- Evrensel ahlâk yasasını, objektif özelliklerin belirlediğini kabul eden düşünürlerin adlarını sayma;

${ }^{21}$ Çelik-Bal, 62-74. 
- Platon, Farabî, Spinoza ve Kant'ın bu konudaki görüşlerini açıklama;

- Söz konusu ahlâk yasasının evrensel dinlere göre temellendirilmesini açıklama;

- Mevlana, Yunus Emre ve Hacı Bektaşî Veli'den hareketle tasavvuf düşüncesinde evrensel ahlâk yasasının nasıl temellendirildiğini açıklama.

İşlenişle ilgili olarak verilen bilgilerde etik ile ahlâk arasında bir ayırım ortaya konmaktadır. Aynı ayırıma, ahlâk yasalarının bilim ve din yargılarından farklı olduğu iddiasında ve ahlâk ile din arasındaki farklılığın ortaya konmasında da rastlanmaktadır ${ }^{22}$.

Ders kitabında ahlâk felsefesinin temel kavramları (iyi-kötü, özgürlük, erdem, sorumluluk, vicdan, ahlâk yasası vb.) tamamen dinîn yanıtlarının bulunmadığı bir düzlemde tanımlanmış, dinlerin bu kavramları anlama biçimlerine yer verilmemiştir. Aynı yaklaşım, özgürlük var mıdır? Ahlâk yargılarının nitelikleri ve ahlâkî eylemlerin nitelikleri gibi ahlâk felsefesinin temel sorularının ele alınış biçiminde de gözlenmektedir ${ }^{23}$.

Etiğgin temel problematiği olarak diğer sorunlar göz ardı edilerek ders kitabında yalnızca "Kişi vicdanı karşısında evrensel ahlâk yasasının olup olmadığı" sorunu ele alınmı̧ ve evrensel ahlâk yasasının mümkün olduğunu savunan görüşler arasında evrensel dinler de yer almıştır. Ancak burada evrensel dinler kapsamına sadece tek tanrılı dinler alınmıştır. Konunun ele alınış biçimindeki yüzeyselliği göstermesi açısından ders kitabındaki anlatıma bakmak yeterli olmaktadır:

"Her dinîn bir ahlàk yasası vardır. Tek tanrılı dinler (Yahudilik, Hıristiyanlık ve İslâmîyet) insanın nasıl davranacağına iliş̧in ahlâk yasasının kaynă̆ı Tanrıdır. Tanrı, her şeyin yaratıcısıdır. Tanrl, iyinin ve kötünün ne olduğunu bilir. Tanrı, insanların uyacakları ahlâk yasalarını "vahiy" yoluyla bildirmiştir. Kurallar tanrı buyruğudur, kesindir. İslâm kültüründe çok önemli yeri olan tasavvuf düşüncesinin büyük bir kısmı ahlâkla ilgilidir... ${ }^{24,}$

Ders kitabı devamla tasavvufun temel özelliklerini özetlemeye çalışmış, ardından da Mevlana, Yunus Emre, Hacı Bektaşî Veli'nin tasavvufla ilgili görüşlerine ağırlık vererek ve kısmen de bu düşünürleri ahlâkla ilişkileri açısından anlatarak konuyu tamamlamıştı̊ ${ }^{25}$.

Diğer dinlerin konuyla ilgili görüşleri ders kitabında bir cümleyle sınırlı kalırken İslâm'ın ahlâk yasası karşısındaki tavrı ise tasavvufun anlatımıyla daraltılmıştır. Bu eksikliklerin hem felsefe programlarında işlenişle ilgili açıklamalarda genişlik kazandırılarak, hem de DKAB programlarındaki ilavelerle giderilmesi gerekmektedir.

\footnotetext{
${ }^{22}$ Felsefe Dersi Programi, 726-728

${ }^{23}$ Çelik-Bal, 76-81.

${ }^{24}$ Çelik-Bal, 89-90.

2s Agy.
} 

Ve Din Kültürü-Ahlak Bilgisi Ögretimi İlişkisi

Felsefe programlarının etik konusunda ortaya koyduğu laik düzleme dayalı yaklaşımı ve ders kitabının dinlerin görüşlerini sınırlı bir şekilde aktarma eğilimine rağmen Harald Delius'un etikin görev ve işlevi konusunda söyledikleri felsefe öğretiminde konuyla ilgili bir yaklaşım geliştirmede yardım edici niteliktedir:

"Felsefî etik, hem betimleyici olabilir ve hem de ahlâksal sorunlarımızın çözümünde bize yol göstermeye yönelebilir (normatif etik). Felsefi etiğin görev ve işlevi bize göre sadece şudur: Çok çeşitli biçimlerde karşımıza çıkan ahlâkları çözümlemek ve böylece çok çeşitli ahlâkların bilgisine sahip olarak kendi ahlâksal eylemlerimizle ilgili kararlarımız ve bu kararlarımızın yol açtığı sonuçlar hakkında bir genel bakış ve daha fazla açıklık kazanmamıza yardımcı olmaktır. ${ }^{26 "}$

Delius'un dediği gibi ahlâkî yargılar arasında taraf olmamak adına görüşlerde açılım sağlayacak her hangi bir unsuru da çözümlemelerimizin dışında bırakmamak gerekmektedir.

\section{Siyaset Felsefesi}

Siyaset, toplumda bireylerin en yoğun olarak ilgilendiği ve özellikle toplumumuzda dinî referansların bolca kullanıldığı alanlardan birisidir. Geleneksel devlet yapısı içinde din-siyaset iç içeliği sebebiyle dinîn siyaset dışında tutulmasına yönelik sistemli çabalara rağmen bu iki kurum arasındaki bağlantılar kısmen de olsa devam etmektedir. Batı dünyasında bile laik devlet yapısındaki oturmuşluğa rağmen, din doğrudan siyasî yapının içinde bulunmamakla birlikte politikaların belirlenmesinde âdeta bir sivil toplum örgütü gibi dışarıdan etken bir faktör olarak devreye girebilmektedir. Bir çok Avrupa ülkesindeki kürtaj karşıtı politikaların yönlendirilmesinde, eğitim programlarında Kilise karşıtı görüşlerin yer almamasına yönelik çabalarda Kilise'nin belirleyici rolü inkâr edilmemektedir.

Dinîn toplum üzerindeki güçlü etkisine rağmen siyaset felsefesi yaparken dinîn sorular karşısındaki tavrının ortaya konmaması, öğrencilerin bu konuda sağlıklı tavırlar geliştirmesinde bir engel olabilmekte ve öğretim alanı dışından gelen sağlıksız yönlendirmelerle doldurulabilmektedir. Nitekim Türkiye'de din öğretiminin tüm süreçlerinde İslâm'ın siyasete ilişkin görüşlerinin dışarıda tutulması nedeniyle siyaset konusundaki radikal ve şiddet yanlısı akımlar belirli zaman dilimlerinde güç kazanmıştır. Dolayısıyla İslâm'ın siyaset üzerine görüşleri, iktidar kaynağını nereden alır? Meşruiyetin ölçütü nedir? Bireyin temel hakları nelerdir? gibi konuların içinde İslâm felsefecilerinin görüşleriyle de desteklenerek verilmesi bir gerekliliktir. Bununla birlikte DKAB dersleri içinde de bu konular uygun üniteler içine monte edilerek sunulmalıdır.

\footnotetext{
${ }^{26}$ Haral Delius, Etik, Günümüzde Felsefe Disiplinleri.
} 
Belirli ekonomik ve siyasî sistemlerin çoğu kez tüm sorunları çözecek hazır reçeteler sunduğuna inanılır. Halbuki en ideal sistemin bile insan faktörüyle iyi işleyeceği bir gerçektir. Bundan dolayı İslâm'ın veya herhangi bir dinî anlayışın hayattan soyutlanarak dört duvar etrafına sıkıştırılması, dinîn toplumsal hayata kalite kazandırabileceği bir çok alandaki katkılarını engelleyecektir. Siyaset benzer biçimde dinîn katkılarıyla zenginleştirilecek ve kalite kazanacak alanlardandir. Siyaset felsefesi ünitesi altında sıralanan davranışlardan "siyaset felsefesini 'Sivil toplumun anlamı nedir? İktidar kaynağını nereden alır? Meşruiyetin ölçütü nedir? Bireyin temel hakları nelerdir?' vb. soruların ışı̆̆ında yorumlama" davranışının kazandırılmasında zorunlu olarak dinîn de alanına girilmektedir.

Nitekim ders kitabında iktidar kaynağını nereden alır? sorusunun cevapları sıralanırken ikinci yaklaşımın iktidarın kaynağı olarak Tanrı'yı gördüğii ve bu yaklaşıma göre devletin Tanrı'nın yeryüzündeki temsilcisi olarak algılandı $\breve{g}$, bu yüzden de devletin iktidarı Tanrı adına kullandığı, devletin Tanrı devleti olduğu belirtilmektedir ${ }^{27}$. Bu görüşü hangi dinî yapı içinde kimlerin savunduğu; tartışmaya açık olup olmadığı gibi açıklamalara yer verilmemiş ve sanki tüm dinlerin bu görüşü savunduğu gibi bir manzara ortaya çıkarılmıştır. Dine atfedilen sağlıksız anlayışların taban tutmasında bu tür yaklaşımların önemli etken olduğunu düşünmekteyim. Zira bir kez dinîn bu tür bir devlet anlayışı ile örtüş̧üğünü iddia ettiniz mi din devleti gibi bir kavram, dinlerin müminleri için de yadsınamayacak bir kavram hâline dönüşecek ve siyaset yaparken de inançları çerçevesinde karar verecek ve eylem yapacaktır. Bu anlayış adeta yakın tarihlerde yaşamış olduğumuz Hizbullah benzeri sağlıksız oluşumlara davetiye çıkarır niteliktedir.

Aynı yaklaşım Meşruiyetin ölçütü nedir? sorusuna verilen cevapların çözümlenmesinde de sergilenmektedir. Meşruiyetin kaynağı ile ilgili olarak ders kitabında şu ifadeler bulunmaktadır:

"Devlet, Tanrı'nın yeryüzündeki temsilcisidir, yaklaşımını savunanlara göre devlet, dinsel misyonu yerine getirmek amaciyla kurulur ve bu misyonu yerine getirdiği sürece meşrudur. ${ }^{28, "}$ Bu görüşün hangi din içinde kimler tarafından savunulduğuna ilişkin hiç bir bilgi verilmediği gibi dinsel misyon kavramının ne ifade ettiğine dair bir bilgiye de yer verilmemiştir. Bu tür hatalı temellendirmelerin radikal yaklaşımlara zemin hazırladığını tekrar hatırlatmak isterim.

$\mathrm{Bu}$ hataların felsefe programları ve ders kitaplarından giderilmesi bir ihtiyaç olarak karşımızda durdugu gibi konu ile ilgili DKAB programları ve ders kitaplarında farklı dinler ve Íslâm dinî temelli tartışmaların yer alması, ögrencilerin siyaset konusunda sağlıklı bir anlayış geliştirmelerine yardımcı olacaktır. İslâm düşünürleri ve bilim adamlarının ideal düzen arayışındaki sorgulamalanı ve görüşlerinden yararlanılması gerekir. Nitekim felsefe ders

${ }^{27}$ Çelik-Bal, 102.

${ }^{28}$ Çelik-Bal, 103. 
kitabında ütopyalar konusunda görüşlerinden alıntılar yapılan Farabî'nin "Erdemli Şehir" isimli eseri ve Yusuf Has Hacib'in "Kutadgu Bilig" isimli eseri olumlu örnekler arasında bulunmaktadır.

\section{Estetik}

Felsefe tarihînde estetikle ilgili tartışmalara baktığımızda "güzel ve güzellik" kavramlarıyla mütemadiyen karşılaşırız. Bu anlamda estetik, güzelin ne olduğunu sorgulayan ve bunun bilgisine ulaşmaya çalışan felsefe dalıdır. "Güzel" kavramı ile ise hem doğadaki ve hem de sanattaki güzel kastedilmektedir. Sanatın ne olduğunu sorgulayan, sanatçının etkinliğini ve sanat yapıtlarını inceleyen felsefe dalı ise "sanat felsefesi (estetik) olarak isimlendirilir.

Felsefe programında ve ders kitabında estetik ünitesi dinle doğrudan bağlantılı bir konu veya yorum bulunmamaktadır. Halbuki gerek özellikle ortaçağ Hristiyan düşüncesi ve gerekse İslâm düşüncesi içinde estetikle bağlantılı ve felsefe programında analiz edilmesi beklenen kavramlardan güzel, yüce ve sanat gibi kavramlar üzerine bir çok tartışma yapılmış; İslâm uygarlı̆̆ı bu tartışmaların bir ürünü olarak dünyaya çok önemli sanat eserleri kazandırmışlardır. Bu kazanımların sürekliliği için aynı tartışmaların hem akademik zeminde canlandırılması ve hem de tartışılan konulardan DKAB aracıllı̆ı ile ögrencilerin haberdar edilmeleri gereklidir. DKAB programları içinde İslâm uygarlığı içinde ortaya çıkan önemli sanat eserlerinden öğrencileri haberdar etmek gerektiği gibi estetik üzerine İslâm düşünürlerinin üretimlerini de sunmak gerekmektedir.

\section{Din Felsefesi}

Din felsefesi, din üzerine felsefi düşünmek, dinîn kendisini, temel kavramlarını ve savlarını soruşturmak olarak değerlendirildiğinden din öğretimiyle doğrudan ilişki hâlinde olan bir felsefe alanıdır. Her ne kadar din felsefesinin konusu, belirli bir din değil de din olgusunun kendisi olsa da öğrenciler, bu konu üzerinde yapılacak tartışmalarda ister istemez içinde yaşadıkları toplumun dinîni merkeze alarak tartışmalara katılacaklardır.

Felsefe dersi programında din felsefesi ünitesi içinde din felsefesinin konusu ve Tanrı'nın varlığına ilişkin farklı yaklaşımlar konu edilmiştir. Bu konulara yönelik olarak ortaya konan amaçlar ve davranışlar şunlardır:

\section{Amaç 1. Din felsefesinin konusunu kavrayabilme} Davranışlar:

1. Dine felsefi açıdan yaklaşımın özelliklerini açıklama

2. Teoloji ile din felsefesinin farkını açıklama

3. Din felsefesinin temel kavramları (Tanrı, vahiy, peygamber, iman, ibadet, yüce, kutsal, vb.)nı açıklama

4. Din felsefesinin temel sorunları (Tanrı'nın varlı̆̆ı, evrenin yaratılışı, vahyin imkânı, ruhun ölümsüzlügüu)nı açıklama 


\section{bilme \\ Amaç 2. Tanrı'nın varlığına ilişkin farklı yaklaşımları kavraya-}

Davranışlar:

1. Tanrı'nın varlığını kabul eden yaklaşımlar (teizm, deizm, monoteizm, panteizm)in temel özelliklerini açıklama

2. Tanrı'nın varlığını yadsıyan Ateizmin özelliklerini açıklama

3. Tanrı'nın varlığının ve yokluğunun bilinemeyeceğini öne süren Agnostizm' in özelliklerini açıklama.

İşlenişle ilgili bilgiler verilirken de bu ünitede "iman" kavramından hareketle öğrencinin ilgisinin din alanında kullanılan temel kavramların değerlendirilmesine, bir başka deyişle dinin felsefi sorgulanmasına çekilmesi istenmiştir. Aynı zamanda bu ünite çerçevesinde dinî yargıların bilimsel, ahlâkî ve estetik yargılardan farkının kazandırılması beklenmektedir ${ }^{29}$.

Ders kitabında ilk amacın 1. ve 2. davranışlarının kazandırılmasına yönelik içeriğin oluşturulmasına yönelik yeterli bir yol gösterme yapılmasına karşın, temel kavramlar ve temel sorularda sorunlar bulunmaktadır. Örneğin temel kavramlarda Tanrı'ya ilişkin farkh anlama biçimleri yüzeysel de olsa verilirken diğer kavramların açıklanmasından dinsel farklılıklara yer verilmemiştir. Din felsefesinin temel sorulan ise sadece sıralanmış, bunların cevapları âdeta bir başka ders için boş bırakılmıştır:

“- Tanrı'nın varlığı sorunu: Tanrı'nın varlığı kanıtlanabilir mi? Tanrı'nın varlığına ilişkin kanıtlamalar ne kadar geçerlidir? gibi sorularla Tanrı'nın varlı̆̆ı sorunu ortaya konulur.

- Evrenin yaratılışı sorunu: Öncesiz ve sonrasız bir varlık var mıdır? Bu sorular da evrenin yaratılışı sorununu oluşturmaktadır.

- Vahiy olanaklı mıdır?: Tanrı, insana vahiy yoluyla bir takım bilgiler verebilir mi? gibi sorular da vahyin olanağı sorununu ifade eder.",

$\mathrm{Bu}$ sorular, öğrencinin kafasında oluşturulup cevapsız bırakılmaktadır. Bu sorulara ilişkin din felsefesi alanında yapılan tartışmalardan öğrencinin haberdar edilmesi gerektiği aynı soruların dinler açısından analizinin DKAB dersleri çerçevesinde yapılması gerekmektedir. Yine Tanrı'nın varlığını kabul edenlerin görüşleri arasına İslâm düşünürlerinden Gazalî dışında kimse alınmamıştır. DKAB derslerinin Tanrı'nın varlığına karşı çıkanlar ve varlığının-yokluğunun bilinemeyeceğini savunanların argümanlarına karşı açıklamalara yer verilecek şekilde yeniden düzenlenmesine ihtiyaç duyulmaktadır.

C. Lise Din Kültürü Ve Ahlâk Bilgisi Programları Ve Ders Kitaplarının Felsefenin Temel Soruları Ve Felsefe Ö̌̆retimi Açısından Değerlendirilmesi

Lise Din Kültürü ve Ahlâk Bilgisi programlarında felsefenin temel soruları ile bağlantılı konular, farklı sınıflara ve ünitelere dağılmış bir hâlde

\footnotetext{
${ }^{29}$ Lise Felsefe Programı, 731-732.

3) Agy.
} 
bulunmaktadır. Felsefe öğretimi açısından bir değerlendirme yapabilmek için bu konuları DKAB programları sistematiğine göre değil, felsefenin temel soruları için felsefe ögretiminde belirlenen sistematik içinde değerlendirmeye çalışacağım.

$\mathrm{Bu}$ arada şunu da ifade etmek gereklidir ki DKAB programlarının yeniden ele alınması sürecinde bu derslerin konu dizilişlerinin yeniden ele alınmasının bir ihtiyaç olduğunu fark ettik. Bugüne kadar yapılan programlardaki konu dizilişleri, klasik ilmihalci yöntem üzerine kurgulanmıştır. $\mathrm{Bu}$ dizilim belki de o günün ihtiyaçlarının ve sorunlarının bir sonucudur. Konu başlıklarının belirlenmesi ve bunların dizilimi konusunda bir kıstas belirlenecekse benim buradaki önerim, felsefenin sorularının temel alınması yönündedir. Çünkü öğrencilerin orta öğretim süreci içinde dinle oldukça bağlantılı konuları tartı̧̧tığı sistematiği din öğretiminde de uygularsak; felsefe öğretimindeki tartışmalarla ilgi kurması ve din öğretiminden gelen bilgileri götürüp felsefe öğretimindeki konteksine yerleştirmesi kolaylaşacaktır. Bu dizilimin ortaya çıkardığı sorunlara değerlendirmelerimiz içinde temas edilecektir.

\section{Felsefeye Giriş-Bilgi Felsefesi-Bilim Felsefesi}

İslâm'ın ve diğer dinlerin bilgiye karşı tutumlarını ortaya koyan ve felsefe öğretiminde öğrencilerin kafalarında oluşan soru işaretlerine cevap niteliğinde bağımsız bir ünite lise DKAB programlanı içinde bulunmamaktadır. Ancak 11. sınıf programları içinde farklı üniteler içinde koruyla ilgili dağınık bilgiler bulunmaktadır.

"Evrensel Bir Din Olarak İslâmlık" başlıklı II. Ünite içinde 3. dersin konusu İslâmî bilgilerin kaynağı ismini taşımaktadır. Derste İslâmî bilgilerin kaynağı olarak kitap, sünnet, icma ve kıyas gösterilmektedir. Ders kitabında İslâmî bilgilerin kaynağı konusunun işlenişinde bilgi, dinsel bilgi ve İslâmî bilgi kavramlarına hiç girilmeden bir peşin kabulle veya geleneksel bir duruşla dört temel bilgi kaynağı kabul edilmekte ve bu bilgi kaynakları hakkında yine aynı perspektife dayalı açıklamalarda bulunulmaktadır. Ancak bu açıklamalarda söz konusu kaynakların bilgi elde etme aracı olarak nasıl kullanılacağına ilişkin bir yöntem tartışması yapılmadı̆̆ı gibi, tarihsel bilgi niteliğindeki bilgilerin dışında bir bilgiye de yer verilmemiştir.

Örneğin ilk kaynak olarak kabul edilen "Kitap"tan anlaşılan Kur'ân'ı Kerim'in tanımı yapılmakta, sure ve ayet kavramları açıklanmakta, tarihsel süreçten bahsedilmekte ve Kur'ân'ın içeriğinin genel hatları verilmektedir. Kısmen Kur'ân'ı anlamaya çalışmanın öneminden bahsedilmekle birlikte öğrenciler için oldukça önemli olan bu konuda basitçe bir yöntem önerisinde bile bulunulmamaktadır. Kur'ân'da yer alan bilgilerin hangilerinin mutlak bilgi ifade ettiği, hangi konuların nasıl anlaşılacağı, bu bilgilerden nasıl yararlanılması gerektiği gibi tartışmalara girilmemiştir. Kur’ân çerçevesinde ögrencilerin çevrelerinde, ailelerinde,, medyada veya diğer derslerde işitmesi olası sorulara ilişkin bir değerlendirme veya cevaplama denemelerinden söz 
etmek mümkün değildir. Halbuki öğrenciler, Selman Rüşdi ve Turan Dursun'la gündeme gelen Kur'ân çerçevesindeki tartı̧̧maları haftalar boyunca TV ekranlarından takip etmekte iken DKAB derslerinin bunları görmezden ve duymazdan gelmesi mümkün değildir.

Aynı eksiklikler sünnet konusun işlenişinde de karşımıza çıkmaktadır. İslâmî bilgilerin ana kaynaklarından ikincisi olarak kabul edilen sünnetin Kur'ân'ı açıklama ve yeni bir dinî hüküm koyma özelliğinden bahsedildikten sonra kısımlara ayrılmakta ve bu alt başlıklar açıklanmaktadır. Ancak burada Peygamber'in davranış ve sözlerinin mutlak bilgi değeri taş1yanları ile taşımayanları arasındaki ayırım ve örneklere yer verilmezken sünnetin önemine ilişkin ayet ve hadislere ağırlık verilmektedir. İcma ve kıyas, bilgi kaynakları olarak anlatılırken bu konuda İslâm bilim adamlarının tartışmaları tamamen gö $z$ ardı edilmekte ve konu bu tartışmalardaki taraflardan birine dayanan tek yanlı bir anlatımla ortaya konmaktadır ${ }^{31}$. İslâmî bilgi kaynakları hakkındaki muhtevayı edinen öğrencinin kafasında aklın kullanılması, bilimsel gelişmelerden yararlanma veya sosyal ihtiyaçların belirleyiciliği konusunda soru işaretleri oluşmaktadır.

Yine aynı konunun sonundaki okuma parçalarından birinde Peygamber'in Enes'e şu öğüdü yer almaktadır:

"Yavrum, kalbinde kimseye karşı kötülük yapma düşüncesi olmadan gününü ve geceni geçirmeye çalış. İyi dinle yavrum! Bu benim sünnetimdir. Kim sünnetimi yaşatırsa beni sevmiştir. Beni seven kimse de cennette benimle beraberdir. ${ }^{32}$,

Sünnetin bağlayıcılığı ile ilgili temel bilgilere sahip olmayan öğrencilere verilen bu anlayış, körü körüne taklide dayalı yanlı̧̧ bir sünnet anlayışının sebebi olmayacik mıdır?

"Evrensel Bir Din Olarak İslâmlık" başlıklı II. ünitenin İslâm'da İlim ve İnsana Saygı konulu 5. dersinde ise İslâm'ın akıl ve ilim dinî olduğu ön plana çıkarılmaktadır. Burada İslâm'ın akla verdiği önem, Kur'ân, hadisler ve tarihsel bağlamda anlatılmakla birlikte bilgi kaynağı olarak kullanılmasına hiç atıfta bulunulmamaktadır. Buradaki anlatımla önceki ünitedeki İslâmî bilgi kaynaklarının anlatımı arasında çelişkiler bulunmaktadır ve bu çelişkiler öğrenciler üzerinde olumsuz etki yapacak niteliktedir. İki ünitedeki anlatımın uzlaştırılması çabasının bulunmaması, aklın önemine rağmen Islâmî bilgi kaynakları arasında nerede durduğu sorusunu akıllara getirmektedir. Ayrıca bu konu, aklın nerede devreye gireceği ve nereye kadar kullanılabileceği gibi soruları cevapsız bırakmaktadır ${ }^{33}$.

Aynı sorun, İslâm' in bilime verdiği önem anlatılırken de karşımıza çıkmaktadır. Burada da Kur'ân ve hadislere dayalı olarak İslâm'ın bilime

${ }^{31}$ Osman Çetin-Mustafa Öcal-Hüseyin Algül, Din Kültürü ve Ahlak Bilgisi, Lise 3, Altın Kitaplar, İstanbul 1993, 33-39.

32 Çetin-Öcal-Algül, 39.

${ }^{33}$ Agy. 
verdiği önem anlatılırken tarihsel süreç içinde İslâm dünyasında bilimsel gelişmelere karşı gelişen direncin sebeplerine girilmemiş, Islâm'ın bakış açısına dayalı ortaya çıkan metodoloji tartışmaları yansıtılmamış ve çeşitli bilimsel akımlar arasında İslâmî bir metodoloji geliştirme çabalarından bahsedilmemiştir. İslâm'ın bilime verdiği değer konusu sanki tarihsel bir süreç içinde yaşanıp bitmiş bir olgudan bahsedilerek gerçekleştirilmektedir. Felsefe öğretimindeki dinsel bilgiye ilişkin verilen bilgilerin düzeltilmesi söz konusu olmadığı gibi öğrencilerin kafasında yeni soru işaretleri bırakmaktadır.

\section{Varlkk Felsefesi}

Felsefenin varlığa ilişkin sorduğu sorularla bağlantılı konular da lise DKAB öğretiminde farklı konular içine dağılmaktadır. Şimdi bu soruların cevaplarının hangi üniteler içinde ne şekilde yer aldığını incelemeye çalışalım.

Varlık nedir? Var mıdır? Temeli nedir? gibi soruların varlığın dinsel açıdan tanımlanmasına yönelik bir ünite, ders veya bilgi lise DKAB programları ve ders kitapları içinde yer almamaktadır. Ancak, varlık ve temeline ilişkin bilgiler ağırlıklı olarak 9. sınıfta İslâm'da Allah inancı, Allah'ın varlığı ve birliği konularında, 10. sınıfta Allah inancı, 11. sınıfta ise evrenin yaratılışı, Allah'ın yaratma sıfatı konuları içinde kısmen verilmektedir. Şimdi bu konular içinde varlığın ne olduğu, var olup olmadığı ve temelinin ne olduğu sorularının cevaplandırılış biçimini programlar ve ders kitaplarindan izleyelim.

Lise DKAB programları varlığın ne olduğu, var olup olmadığı ile ilgili tartışmalara hiç girmeden varlığın temeli sorusunun cevabı ile işe başlamaktadır. Allah'ın varlığı ve vahdaniyeti, 9. sınıfta "İlahî Dinlerdeki Ortak Yönler" başlıklı konudan hemen sonra İslâm'ın Allah inancı konusu içinde anlatılmaktadır. Burada İhlas suresi ve Kelime-i Tevhit'teki anlamlara dayalı olarak İslâm'ın Allah görüşünün önceki konuda anlatılan diğer dinlerin Tanrı inancindan farkı ortaya konmakta ve Allah'ın sıfatları sıralanmaktadır. Bu sıfatlar arasında "var olma, öncesi olmama, sonu bulunmama, birlik, sonradan olanlara benzememe ve kendi zatıyla var olma" gibi varlık felsefesiyle bağlantılı kavramlardan söz edilmesine rağmen bunlarla ilgili hiç bir açıklama yapılmamaktadır. Bu kavramlar, İlahî dinlerdeki ortak yönler konusu içinde de geçmekte ve ama yine açıklamalara yer verilmemektedir ${ }^{34}$.

10. Sınıfta ise "İslâm'da İnanç Esasları" başlı̆ğ bilgiler bulunmaktadır. Burada "Allah İnancı" başlıklı konu altında Kur'ân'ın Allah'ın varlığı ve birliği konusu üzerinde önemle durduğu belirtilmekte ve Allah'ın sıfatları ile ilgili açıklamalara yer vermeden kısa

\footnotetext{
${ }^{34}$ Rami Ayas-Günay Tümer, Lise I Din Külıürü ve Ahlak Bilgisi, Milli Eğitim Bakanlığı Yayınları, Ankara 1983.65-68.
} 
bilgilerle konu geçiştirilmektedir. Her ne kadar ders kitabı burada geleneksel öğretimdeki sıfatlar sıralaması yerine Kur'ân'daki Allah anlatımını esas almışsa da konu ile ilgili temel kavramlar hakkında fikir sahibi olmayan ögrencilerin bu açıklamaları algılamaları zor olabilir. Kur'ân'daki Allah tasavvurunun verilmesinden önce, felsefenin varlıkla ilgili temel sorularının cevaplandırılmasında dinî temelli bir yaklaşım kazandırılırsa algılama zorluklarının önüne geçilmesi de mümkün olabilecektir. Öğrenciler belirli bir birikime sahip olduktan sonra doğrudan Kur'ân'a müracaat edilerek yapılan alıntılarla ortaya konan Allah tasavvuru, ögrenciler tarafından daha kolay algilanabileccktir.

11. Sınıfta varlığa ilişkin sorulan soruların cevapları program ve kitaplarda daha bir netlik kazanmaktadır. Evrenin yaratılışı, Allah'ın yaratma sıfatı, Kur'ân'a göre dünyamız, insanın yaratılışı ve üstün varlık insan gibi konular içinde varlık felsefesiyle bağlantılı soruların cevapları parça parça karşımıza çıkmaktadır.

Lise 3. sınıf DKAB programlarının ilk ünitesi "İslâm ve Evren" başlığını taşımaktadır ve bu ünite evrenin yaratılışı, Allah'ın yaratma sıfatı ve insanın yaratılışı gibi konu başlıkları altında varlıkla ilgili sorulara İslâm dinî açısından cevaplar vermeye çalışmaktadır. Ancak hemen belirtelim ki buradaki cevaplar âdeta felsefenin soruları karşısında bilimin varsayımları ve verdiği cevaplara karşı dinsel açıdan bir savunma üslubu taşımaktadır. Felsefenin bu konuyu tartışması, işlenişler sırasında tamamen göz ardı edilmiş ve yukarıdaki varlık felsefesi sorularının cevaplandırılması için gerekli kavramsal alt yapının oluşturulması için hiç bir çabada bulunulmamıştır.

Evren'in yaratılışı konusuna bilim ve evrenle ilgili temel bilgiler verilerek başlanmaktadır. Daha sonra ise Kur'ân'ın konu ile ilgili yaklaşımı ortaya konmakta, ancak bilimin evren konusundaki yaklaşımı esas alınarak Kur'ân'ın evrenle ilgili yaklaşımı anlaşılmaya çalışılmaktadır. Bu yapılırken de öğrencileri tartışmaya teşvik etme çabası bulunmadığı gibi İslâm teoloji geleneğinde hiç de fazla rağbet görmeyen bir bilim-din uzlaştırma çabası temel olarak alınmıştır ${ }^{35}$. Bilimsel verilerin değişmesi hâlinde burada geliştirilen Kur'ân'ı anlama biçimlerini nereye koyacağımız ve kafalardaki soru işaretlerini nasıl çözeceğimiz ayrı bir sorun olarak karşımızda durmaktadır.

Örneğin ders kitabında, yaratılışla ilgili Mülk 1, En'am 73, Bakara 29, Ankebut 44 , İbrahim 12-13 vb. ayetlerin meallerini sıraladıktan sonra şu açıklama yapılmaktadır:

"İşaret ettiğimiz ayetlerde 'bütün canlıların sudan meydana getirildiği' belirtiliyor. 'Duman halinde olan gök'ten bahsediliyor. Anlaşılıyor ki arş, kainat yaratılmadan önce su üstünde idi. Yüce Allah diriliği ve canlılı̆̆ bu sudan meydana getirdi. Bilimsel araştırmalar bugün gösteriyor ki, canlılıar susuzluğa dayanamazlar. Çünkü bir su moleküliu vücutta 7-14 gün kalıyor, sonra atılıyor ve yerine canlılık sağlayacak yeni su iyonları alınıyor. Bir

${ }^{35}$ Çetin-Öcal-Algül. 12-13. 

Ve Din Kültürü̈-Ahlak Bilgisi Ögretimi Illişkisi

hücrenin sağlıklı olması da çevresindeki su iyonlarının dengesine bağlıdır. Böylece canlının, fonksiyonunu yerine getirmesi demek olan diriliğin temel ફ̧artının su olduğunu Kur'ân ayeti bize 15 yüz yıl önce haber vermiş oluyor...İhtimal ki evren bir zamanlar sıvı hâldeydi. O durumda ne kadar kaldığını Allah bilir. Sıvı daha sonra gaz durumuna dönüştü. Böylece evrenin aslı gaz kütlesi hâline geçti. Yüce Allah bir patlama ile evrenin oluşumuna yeni bir şekil verdi. Bu patlama sonunda güneşten çevreye ateşten toplar savruldu. Ayetlerde de belirtildiği gibi Cenabı Hak, hava, su, toprak gibi unsurlara bugünkü özelliklerini verdi; ssısını, dönüş hızını ve eğikliğiyle atmosferini insan ve diğer canlıların yaşayışına elverişli hâle getirdi. Nitekim 'Ardından yeri düzenlemiştir. Suyunu ondan çıkarmış ve otlak meydana getirmiştir. (Naziat 30-31)' ayeti de buna işaret etmektedir. Ayrıca bu ayetteki 'yeri düzenlemiştir' ifadesi gramer bakımından incelendiğinde düzenlenen şeklin elips anlamını da içerdiği anlaşılmaktadır..."36

Bilimsel verilere dayalı olarak Kur'ân'ı yorumlama çabaları, İslâm tefsir tarihînde yeni olmamakla birlikte, özellikle son yıllarda bilimsel çalışmaların baş döndürücü hızı nedeniyle de fazla kabul görmemektedir. Buradaki yorumları göz önüne alırsak, evrenin oluşumunu açıklayan bir çok teoriden sadece birisinin (bing-bang teorisi) Kur'ân'ın yaratılışa ilişkin görüşleriyle örtüştüğü sonucuna ulaşmamız gereklidir. Halbuki, yazarların ders kitabına aldıkları teoriyle birlikte evrenin oluşumunu açıklayan başka teoriler de bulunmaktadır ve bunların hiç birisinin doğruluğu bilim çevreleri tarafından ittifakla kabul edilmemektedir. Kur'ân'ın kullandığı kelimelerin etimolojik kökenlerine inerek bilimsel sonuçlara ulaşmak da genel kabul gören bir bilimsel yöntem değildir. Zira Kur'ân bilim yapma kitabı değildir böyle bir iddiası da bulunmamaktadır. Ayrıca siz bilimsel bir çaba sonucu elde edilebilecek bilgiye, bilgi ortaya çıktıktan sonra Kur'ân yoluyla ulaşmaktasınız. Kur'ân'dan hareket edilerek ulaşılan bir bilimsel sonuç ortaya konabilmiş midir?

Ders kitabı aynı yaklaşımla dünyanın yuvarlaklığı ve dünyanın kendi etrafında dönmesi gibi bir çok bilgiyi Kur'ânî referanslarla açıklamakta ${ }^{37}$ ve öğrencilerin "öyleyse Müslümanlar ve tüm dünya niye yüzyıllar boyunca dünya ve evrenle ilgili bir çok yanlı̧ bilgiyi taşıyıp durdular?" muhtemel sorusunu cevapsız birakmaktadır.

Ders kitabının tercih ettiği yöntem içinde varlık sorunu hiç söz konusu edilmemiş, varlığın temeli konusunda da dinsel bir açıklama biçiminden çok bilimsel açıklamalara karşı savunmacı bir yaklaşım sergilenmiştir. Varlığın temeline ilişkin soruya yanıt niteliğindeki bilgiler, "Allah'ın Yaratma Sıfatı" başlıklı konu içinde bulunmaktadır. Ancak bu konunun işlenişinde de İslâm düşünce tarihî içindeki tartı̧̧malarda ortaya çıkan açıklamalardan bahsedilmemekte, bilimsel açıklamalara dayahı anlatım sürdürülmektedir. Bu nok-

\footnotetext{
${ }^{36}$ Çetin-Öcal-Algül, 13.

${ }^{37}$ Çetin-Öcal-Algül, 12-17.
} 
tada dikkati çeken en önemli nokta, yaratılıs konusunda Allah'ın yaratmasının sürekliliğine yapılan vurgudur. Ancak yaratılan sistemin "sünnetullah" kavramı çerçevesinde açıklanırken sürekli yaratma ile, bir kanunlar dizisi yaratıp geriye çekilme arasında oluşan zıtlığgı giderecek açıklamalara yer verilmemiştir. Ders kitabında konu ile ilgili farklı anlayışların tartışmalarına yer verilmediği gibi ders kitabı yazarlarının tercih ettiği görüşten kaynaklanan tutarsızlıklar anlatıma yansımıştır. ${ }^{38}$ Bu çelişkilerin öğrenciler üzerindeki olumsuz etkilerini ayrıca tartışmaya gerek yok sanıyorum.

Varlık felsefesinin "evrende düzen var mıdır?" sorusu hem bu konu, hem de daha sonraki "Kur'ân'a Göre Dünyamız" konusu içinde cevaplandırılmaya çalışılmıştır. Ancak bu bilgiler felsefe öğretimindeki sorular göz önünde bulundurulmadan işlenmiş; soruların cevapları sistematik biçimde DKAB dersleri içinde verilmemiş; çelişkili anlatımlar da karşımıza çıkabilmektedir ${ }^{39}$.

"İnsanın bu dünyadaki yeri nedir?" sorusunun cevabı ise "İnsanın Yaradılışı" başlıklı ders içerisinde verilmeye çalışılmıştır. İnsanın yaratılışı bu konu içinde Kur'ân'a dayalı olarak anlatılırken, öğrencilerin kafasında buradaki sembolik anlatımlardan kaynaklanabilecek soru işaretleri dikkate alınmamıştır. Örneğin "Allah, insanların cezalandırılmasından zevk mi almaktadır ki onları yaratmuş ve çetin bir sınav için dünyaya göndermiştir. Hem onu cennetteki nimetlerden uzaklaştırarak dünyanın zor fiziksel şartlarının içine atımıs, hem de burada üstesinden zorlukla gelebilecekleri iyikötü mücadelesinden alnının akıyla çıkmasını beklemiştir". Üstelik bu sınavda başarısız olanları ise cehenneminde yakmakla tehdit etmektedir! Varlık kavramına ilişkin İslâm düşünce tarihîndeki tartışmalara yer verilmediğinden "Madem hiç bir şey yoktu, Allah neye ol! diye emretti?" şeklindeki soruların öğrenciler tarafından sorulmasına neden olabilmektedir.

"İnsan Soyunun Devamı" konusu da yazarlar tarafından bilimsel temellendirme kaygisı altında ayetlerin yorumlanması suretiyle anlatılmaktadır. "İnsanın Yaratılışına Miispet İlimin Bakışı" başlıklı konuda da benzer yaklaşım gözlenmektedir. "Üstün Varlık Insan"da ise Islâm'ın insandan beklentileri ve yükümlülükleri yani felsefe öğretimindeki düzen içinde insanın rolünün sorgulanmasına dinîn cevabını vermektedir bir anlamda.

Oluş, var oluş, ideal varlık, mümkün varlık, zorunlu varlık gibi kavramlar DKAB program ve ders kitaplarında görmezden gelinmiştir. Eğer bu kavramlar felsefe öğretimi içinde konu edilerek öğrencinin karşısına çıkarllıyorsa, din ögretiminin de konu edinmesi beklenmelidir. Bu kavramların tek bir dinîn bakış açısıyla değil; dinlerin farklı bakış açılarıyla birlikte dinler içindeki dikkate alınması gereken farklılıkları da içerecek şekilde geniş bir bakış açısı altında incelenmesi gerekir.

\footnotetext{
34 Agy.

39 Agy.
} 
Öğrencilerin hakkında en çok soru sordukları konulardan birisi olan ve felsefe ögretiminde gündemlerine bir kez daha taşınan ruh konusu da din öğretiminin cevapsız bıraktığı alanlardan birisidir.

Yukarıdaki bölümlerde de değindiğimiz gibi, DKAB lise programlanı ve ders kitapları, felsefenin sorularını cevaplandırmada yetersiz olduğu gibi, ilgili konuların İslâmî bir bakış açısıyla da ortaya konmasında sıkıntılar bulunmaktadır. Kullanılan malzeme ve bu malzemenin yorumlanmasında esas alınan yaklaşım kendi içinde tutarsızlıklar ortaya çıkarmakta bu tutarsızlıklar da yeni zihinlerde yeni soruların belirmesine neden olmaktadır.

\section{Ahlâk Felsefesi}

Ahlâk felsefesinin felsefe öğretimine konu olan soruları, insanın ahlâkî eylemde bulunurken özgürlüğü, evrensel ahlâk yasasının imkânı ve ahlâkî eylemin amacına yönelik görüşleri ortaya koymaya yöneliktir. Bu sorular, tüm dinlerin ortaklaşa müdâhil olduğu bir alanı karşımıza çıkarmaktadır. Hemen tüm dinler, ahlâk felsefesinin bu sorulanına cevap verme çabası içinde bulunmuşlardır. Liselerdeki DKAB programı ve kitaplarında bu sorulara İslâm'ın cevabı bütünlük içinde yer almamakla birlikte farklı sınıflardaki farklı üniteler içinde dağınık bir şekilde cevaplar bulunmaktadır. Lise DKAB programında ahlâkî konular ortaya konurken önce tüm dinlerin ortak ahlâkî yaklaşımı kazandırılmakta, daha sonra ahlâkın tanımı, dinle ilişsisisi, ahlâkın değişmezliği ortaya konarak bir temel oluşturulmaya çalışılmaktadır.

Onuncu sınıfta ise İslâm'ın ahlâka verdiği önem, ahlâk vicdan ilişkisi, fazilet (erdem) kavramı, sorumluluk ve doğruluk kavramları farklı üniteler içinde işlenmektedir. On birinci sınıfta ise İslâm'ın ahlâkî alandaki isteklerinden bir kısmı işlenmekte, iyilik kavramının açılımı yapılmakta ve ahlâkın toplumsal boyutu ile ilgili bilgiler verilmektedir.

Ahlâk açısından dinlerin ortak yönleri anlatılırken ders kitabında, ahlâkın dayanağı olarak iman ve sevgi faktörleri ön plana çıkarılmaktadır. Ancak ceza korkusu ve mükafat ümidi di dinlerdeki ortak ahlâkî dayanaklar arasinda belirtilmektedir. İyi-kötü, helal-haram, günah-sevap, yap-yapma gibi hükümlerin ahlâkî davranışlara yönelten etkenler olduğu belirlendikten sonra ahlâkî davranışları mümkün kılanın irade olduğu ve insanın da iradesini kullanmakta hür olduğuna vurgu yapılmaktadır ${ }^{40}$. Daha sonra ise dinlerdeki ortak hükümlerden örnekler verilmektedir. Bu konu altında ahlâk felsefesinin soruları ile ilgili olarak dinlerin buluştuğu ve veya ayrıldığı noktalara girilmemekte ve aralarındaki tartışmalara yer verilmemektedir.

Ahlâk konusunun ayrıntılı bir şekilde ele alındı̆̆ $\breve{l}_{1}$ yer, lise I. sınıftaki "Din ve Ahlâk" başlıklı ünitedir. Burada ahlâk hakkında genel bilgiler verilerek konuya giriş yapılmış ve insanın eylemde bulunan bir varlık olduğu, değerleri duyup yaşadığı açıklanmış, değer çeşitleri ve özellikleri ayrıntılı bir şekilde açıklanmış, ahlâkî değerlerin bunlar arasındaki yeri net

Ayas-Tümer, 65-66. 
bir şekilde belirlenmiştir ${ }^{4}$. Ancak buradaki açıklamalarda insanın ahlâkî eylemde bulunurken özgürlüğü ve evresel bir ahlâk yasasının imkanı tartışmalarına girilmemişken, ahlâkî eylemin amacına ilişkin "değer" konusu kapsamında bazı bilgiler verilmektedir. Ahlâkî eylemin amacının yapıp eden, değerleri duyup yaşayan bir varlık olan insanın ahlâkî eylemi de bu değerlerle uyum sağlamak amaciyla yaptığı sonucuna ulaşabiliriz. Bununla birlikte değer konusunda dinsel bir yaklaşım ortaya konmamış; sadece ahlâkın iyi-kötü değer ölçüsü ile, dinîn günah-sevap değer ölçüsüne cevap veren değerlerin aynı rolü oynayan değerler olduğu iddia edilerek safiyetiyle yaşanan dinîn, ahlâk yaşayışının yüksek değerlerini daima desteklediği ve onlarla bütünleştiği sonucuna ulaşılmıştır ${ }^{42}$. Burada yazarların ahlâk ve dinî birbirinden bağımsız alanlar olarak görme eğilimi içinde oldukları düşünülebilmektedir.

Ahlâkın dinle ilişkisi ise ayrı bir ünite içinde bağımsız bir konu başlığı altında incelenmektedir. Burada dinîn de ahlâkın da köklerinin insanda bulunduğu noktasından hareket edilerek tarihî süreç içinde insanların ahlâkî yaşantıyla, dinî yaşantıyı birlikte sürdürdükleri ortaya konmaktadır. İnsanların dillerinde ve sanatlarnndaki zenginliğin ahlâkî yaşantılarına da yansıdığını, bu zenginliğin kaynağının da insan olduğu sonucuna ulaşılmaktadır. Bununla birlikte dinî yaşantı dışında ahlâklılığın olmayacağı iddiasına karşı çıkılmakta; iki kurumun da insana dayalı olarak ortaya çıtığı noktasından hareket edilerek insanın bı farklı boyutlarının insan varlığının bütünlügüüü ifade ettiği hatırlatılmakta ve bu boyutlardan her hangi birisinin yok sayılmasının yabancılaşmayı beraberinde getireceği değerlendirilmesinde bulunulmaktadır. Aynı konu altında bütün dinler, ahlâk görüşleri ve hukuk düzenlerinin insanların neleri yapması gerektiği ya da yapmak zorunda olduğu ve neleri yapmaya izinli olmadığı üzerinde bir takım inanışlar taş1dığı vurgulanmakta ve tüm bunların birlikte yaşama sonucu ortaya çıktığı ve bunun sonucunda da birlikte yaşamın gerçekleştiği belirlenir ${ }^{43}$. Ders kitabında bu şekilde ahlâkı dinden soyutlama iddiasındaki felsefe öğretiminin ortaya çıkardığı boşluğu doldurmakla birlikte yine de temel sorularla henüz bir ilişki sağlayamamıştır.

Lise DKAB ögretiminde ahlâk felsefesinin temel sorularıyla somut bir ilişki ilk kez "Ahlâkın Değişmezliği” konusunda kurulmaktadır. Konu, ahlâkın evrensel ve değişmez. bir olay olduğu kabulüyle başlamakta ve tarih boyunca karşımızda duran bir olgu olduğuna dikkat çekmektedir. Ahlâkî isteklerde biçimleri ne olursa olsun, her insan topluluğunun genel ve temel şartları bulunduğundan hareketle değişmeyen ortak isteklerle yaşamın gerçekleştirildiği belirlenmektedir. Bu değişmezlerle birlikte farklı toplumlarda somut bir biçim almış olan tek tek her ahlâkın kendi topluluk tarihî

${ }^{41}$ Ayas-Tümer, 78-87.
${ }^{42}$ Ayas-Tümer, 81-87.
${ }^{43}$ Ayas-Tümer, 88-89. 
bakımından bir takım şartlara bağlı olduğu ortaya konmaktadır. Yazarlar, ahlâkın evrensel değerler oluşturma amacından ziyade alışılan değerlere dayalı olarak çıktığını şu sözleriyle ortaya koymaktadırlar:

"Toplumdan topluma değişen değerlilik ve değersizlikler, buyruklar ve yasaklar özellikle alışılan değerler alanında ortaya çıkmaktadır. Ahlâkların çok kez birbirlerine karşıt görünüşleri, çeşitli başkalıkları, insanın evrensel mahiyetteki ahlâklılığından değil, bundan ileri gelmektedir. ${ }^{44}$,

Ahlâk ve sorumluluk ünitesi içinde ise ahlâk felsefesinin temel kavramlarından sorumluluk açıklanmaktadır. Burada sorumluluğun ahlâkî davranışların sonucu olarak ortaya çıktığı düşüncesinden hareket edilmekte ve kişinin, yapıp ettiklerinden ötürü, toplulukça sorumlu tutulmasının ise o kişinin dışında daha önce oluşmuş genel ahlâk anlayışından, alışılan değerler çerçevesinde söz konusu edilen örf ve adetlerden ileri geldiği belirlenmektedir. Toplum içinde, kişinin yapıp ettiklerinden sorumlu tutulabilmesi için hür olması ve aklına ve şuuruna hâkim olması gerektiği şartları ortaya konduktan sonra baskı altında yapılanlardan dolayı insanların sorumlu tutulamayacağı belirlemesi yapılmaktadır. Daha sonra sorumluluk kavramının açıklanmasına yönelik ayet ve hadisler referans olarak sunulmuştur. Ancak kavramın açılımının yapıldığı bölümdeki temellendirmeler ile burada kullanılan ayet ve hadisler arasında ilişki kurulması biraz zor görünmektedir. Örneğin kullanılan ayet ve hadislerde sorumluluğun nedeni olarak peygamberlerin gönderilmesi gösterilirken önceki konuda bundan hiç söz edilmemiştir. Aynı şekilde sorumiluluk kavramının açılımı yapılırken de hiç dinî referanslara gönderme yapılmamıştır. Bu eksiklikler, sorumluluk kavramının İslâmî bakış açısından algılanmasında sorunlara neden olmaktadır.

Ahlâk felsefesinin temel kavramlarından biri olan doğruluk kavramı da lise DKAB programı çerçevesinde açıklanmaktadır. Ancak bu açıklamalarda da yine dinsel referanslar kullanılmamış, dinsel bir bakış açısından yaklaşılmamıştır. Doğruluk değerinin yönettiği eylemler ve tanıklıkların, olaylarla doğrulanan ahlâkî görünüşler olduğu belirlendikten sonra bu değerin toplum içinde işlerlik kazanmasının gerçekçi bir düşüncenin gelişmesine, bilim anlayışının olgunlaşmasına ve bilimsel araştırmalarda kolaylıklar sağlamada yardımcı olacağ iddiasına yer verilmektedir $^{45}$.

Ahlâk felsefesinin temel kavramlarından vicdan ve bu kavramın ahlâkla ilişkisi lise 2. sınıf DKAB programlarında "İslâm'ın Ahlâka Verdiği Önem" başlıklı ünite içinde konu edilmektedir. Vicdan kavramı, kişiye kendi davranışları hakkında bir yargıda bulunmaya iten, kişinin kendi ahlâkî değerleri üzerinde dolaysız ve kendiliğinden yargılama yapmasını sağlayan güç olarak tanımlanmaktadır. İslâm dinînin de vicdana önem verdiği, insanlarda bu yeteneğin sürekli ön planda tutulmasını istediği belirlendikten sonra, bu yeteneğin geliştirilmesi için bir metot ortaya koyulmaya çalışılır. Ancak ders

\footnotetext{
${ }^{44}$ Ayas-Tümer, 96.

45 Ayas-Tümer, 127-128.
} 
kitabındaki anlatımla vicdanın en başta verilen tanımından farklı olarak, geleneksel merhamet anlayışı anlamına doğru bir kayma gözlenmektedir. Yazarların vicdan kavramını merhamet şeklinde anladıkları şu alıntılarda gözlenmektedir:

"İslâm dinî her konuda olduğu gibi vicdan konusunda da orta yolu tavsiye eder. İnsanın vicdansız denilecek kadar katı kalpli olmasını istemediği gibi, pısırıklığa ve aşırı yufka yürekliliğe sebep olabilecek kadar vicdanlı olmasını da istemez...Örneğin yasalara ve kurallara karşı suç işlemiş bir arkadaşına karşı vicdanlı davranarak acıyan, bu nedenle onu korumaya çalışan insan, hem arkadaşına hem de kendine zarar verir... ${ }^{40}$,

Buradaki açıklamaların bir tür oto kontrol mekanizması olan vicdanla bir ilişkisi yoktur. Belki merhamet kavramını açıklamaktadır. Nitekim konu içinde kullanılan resim alt yazısı da bu düşüncemi desteklemektedir: "bütün canlılara vicdanlı davranmalıyız!". Ayrıca İslâm'ın vicdan konusundaki orta yolunun ne gibi özellikler taşıdığı açıklanmadığı gibi, bu konudaki yargıları destekleyecek dinsel referanslar da kullanılmamıştır ${ }^{47}$.

Nitekim daha sonraki konuda vicdanın ahlâkla ilişkisi ortaya konurken tekrar ilk tanıma dönülmekte ve davranışlar nitelendirilerek ahlâka kaynaklık ettiği düşüncesi ortaya konmaktadır. Bununla birlikte yanılabilirliği nedeniyle başlı başına bir karar kaynağı olmadığı; eğitim doğrultusunda yönlendirilebileceği; bunun sonucunda da ahlâkî anlayışların toplumdan topluma değişebileceği iddia edilmektedir. Konu, ahlâkın da vicdanın da ortak kaynağının toplum, dolayısıyla din olduğu yargısına ulaşılarak sonlandırılmaktadır ${ }^{48}$. Halbuki lise 1 programlarına dayalı ders kitabında bu kaynak bireye dayandırılmıştır. İki ders kitabının aynı kondu ulaştığı farklı sonuçlar, öğrenciler üzerinde anlamayı zorlaştırıcı niteliktedir.

\section{Siyaset Felsefesi}

Felsefe ögretiminde siyaset kavramından bahsedilirken, devlet ve toplum yönetimiyle ilgili tüm etkinlikler anlaşılmaktadır. Siyaset felsefesi ise siyasal varlık alanının dayandı̆̆ı varsayımlar hakkında bir soruşturma olgusudur. Dinler, devlet ve toplum yönetimiyle ilgili etkinliklerin düzenlenmesine yönelik görüß̧ bildirmekten geri durmadıkları gibi; devlet ve toplumları yönetenler de uygulamalarını dinle temellendirdiklerinde kendilerini daha güçlü hissetmişlerdir. Bu tarihsel düşüncenin etkileri hâlen çağdaşlaşma yolunda çaba gösteren toplumlarda gözlenebilmektedir. Çağdaş toplum ve devletin özgü? ve katılımcı bireylerinin oluşturulmasında eğitim çevresi içindeki etkinliklerde vatandaşlık ögretiminin yanında felsefe ve din öğretimi de önemli rol oynamaktadır.

${ }^{46}$ A. Hikmet Eroğlu-Mehmet Katar-Kaya Kuzucu, Lise 2. Sintf Din Kültürü ve Ahlak Bilgisi Ders Kitabı. Özgün Yayıncılık, 23-24.

47 Agy.

48. Agy. 

Ve Din Kültürü-Ahlak Bilgisi Ögretimi Îlişkisi

Felsefe öğretiminin, siyaset felsefesinin temel sorularını tartışırken dinlerle ilgili olarak verdiği yanlış bilgilere temas etmiştik. Buradaki bilgilerin, radikal tavırlarıyla öne çıkan marjinal akımların din anlayışlarıyla örtüştüğünü söylediğimizde abartılı bir iddiada bulunmamış oluruz. Bu şekildeki yanlış bilgilendirmeler yerine felsefe öğretimindeki hatalı anlayışlar düzeltilmekle birlikte $\mathrm{DKAB}$ derslerinin de konu ile ilgili sağlıklı düşünceler üretilebilecek malzemeyi sunması gerekmektedir.

Şimdi mevcut lise DKAB program ve kitaplarının iktidar, meşruiyet ve egemenlikle ilgili olarak bir anlayı̧̧ kazandırıp kazandırmadığı ve siyasetle ilgili olarak hangi konuları nasıl bir yaklaşım içinde incelediğini görelim:

Lise 1. sınıf DKAB ders kitaplarında din temelli bir siyaset anlayışı oluşturmanın temelleri dinîn tanımında atılmaya başlanmaktadır. Her ne kadar önce sosyolojik temelli bir tanım yapılmış olsa da daha sonra, İslâm bilginleri tarafından yapılmış bir tanım olarak geleneksel ilmihal kitaplarında da karşılaşabileceğimiz bir tanım karşımıza çıkarılmaktadır. Dinî, Allah tarafından kurulan, mensuplarını dünya ve ahirette mutluluk ve kurtuluşa ulaştıran inanı̧ ve davranışlar bütünü olarak anlayan bu tanımlama çabasında, geleneksel anlama biçiminden kaynaklanan eksiklikler bulunmaktadır. Böyle bir tanımdan hareket eden ögrenci için, "bu dinîn gereğidir" denen her tutum otomatik olarak Allah'a dayandırılacaktır. Halbuki Allah, bu anlayışta olduğu gibi "din oluşturucu" değildir. Dinî oluşturan insanlardır ve dinîn içindeki kuralların önemli bir bölümü vahyin ilk geldiği an ve yer merkez olmak üzere dönemler ve mekanların üst üste katkılarıyla ortaya çıkmıştır. Her bir kurumsallaşmış dinîn, vahiyle örtüştügüu parçaları bulunmasına rağmen, vahiyle anlatılan din kavramı ile kurumsallaşan dinîn karakterleri her zaman birbirinin aynı demek değildir. Aynı zamanda tanımda netleştirilmeyen dinsel alanla dinsel olmayan alan ayrımından dolayı Allah'ın siyaset de dâhil olmak üzere her alanda müdâhil olduğu gibi bir düşünce ortaya çıkabilmektedir. Halbuki din kavramı etrafında İslâm bilginlerince yapılan çok farklı tanımlama denemeleri olduğu gibi Kuran'ın da kullandığı değişik anlamlar bulunmaktadır ${ }^{49}$. Din siyasete bir bakış açısı elbette getirecektir; eğer bu bakışın kendi bireysel düşüncelerini din gibi pazarlamak isteyenlerce düzenlenmesi istenmiyorsa, öğrencilere farklı yaklaşımlar hakkında bilgi vererek kendi düşüncelerini oluşturma ve ortaya konan düşünceleri de değerlendirebilme becerisini kazanma şansı verilmelidir.

Lise DKAB kitaplarının el attığı konulardan birisi de "Ehli Beyt Sevgisi" meselesidir. Önemli oranda siyasî etkenlerden ortaya çıkmış olan bu sorun, sanki dinsel bir konu imiş gibi programlar ve kitaplar arasına dâhil edilmiştir. Halbuki bu konu iktidarın kaynağı nedir? sorusunun cevaplandırılmasında ortaya çıkmış olan tartışmaların ürünüdür. Bu tartı̧̧malar sonucu da iki büyük dinî kurum İslâm dünyasını etkisi altına alacaktır. Din ögretimi, hem bu iki büyük yapılanmadan birisini (Şia) hem de Anadolu

49 Tanımlar için bkz. Ilmihal I (iman ve Ibadetler), İSAM Yayınları, Ankara 2001. 
topraklarındaki yansıması olarak yüzyıllarca Osmanlı'yı ve bu toprakları kültürel açıdan önemli bir biçimde etkileyen düşünce ve yaşama biçimini (Alevilik) görmezden gelmektedir. Din Kültürü ve Ahlâk Bilgisi öğretimi, bu konuları görmezden gelince öğrenci etrafında yapılan tartışmalara hangi kaynaktan edineceği bilgilerle katılacaktır?

Lise I DKAB programları ve ders kitapları "Devlet" kavramına ilişkin dinsel bakı§̧ açılarını yansıtan bir alt yapı oluşturmadan "Devlete Karşı Görevlerimiz" konusunu işlemektedir. Bu konu altında kanunlara saygı, vergi vermek, askerlik ve seçimlere katılmak konuları işlenmektedir. Devlet olgusuna karşı sağlıklı bir tavır geliştirememiş olan öğrenciler üzerinde bu konuların mutlak itaat sonucu dışında bir değer ortaya çıkarmayacağı açıktır. Lise 2. sınıf programlanı ve ders kitaplarında işlenen "Milli Birlik ve Beraberlik" konulu ünite altında vatan ve devlet kavramlarının işlenmesinde de aynı hatalı yaklaşım sergilenmektedir. Lise 3. sınıfta ise "Atatürk ve Dinîmiz" konusu altına laiklik kavramı açıklanmaktadır.

Siyasetle ilgili tüm bu konulara rağmen felsefe öğretimindeki temel sorunların (Devletin varlık nedeni nedir? Fonksiyonları nelerdir? İktidarın Kaynağı nedir? gibi sorular ve eşitlik, adalet gibi kavramlar) din temelli çözümlemelerine hiç girilmemiştir. Halbuki daha önceki konularda bu soruların cevaplandırılmasında felsefe ögretiminin hatalı bir şekilde dine isnat edilen görüşleri öğretim kapsamına aldığından söz etmiştim.

\section{Estetik}

Felsefe, ortaya konan ilk düşünce ürünü eserlerden itibaren güzel ve güzellik kavramlarını sorgulamıştır. Estetik denilince kısaca güzelin ne olduğunu sorgulayan ve bunun bilgisine ulaşmaya çalışan felsefe dalı anlaşılı $r^{50}$. Bu çerçevede sanat, taklit olarak, yaratma olarak ve oyun olarak tartışılmıştır. Sanatın yaratma olup olmadı̆̆ İslâm sanat tarihî içinde de tartışma konusu olmuş ve ortaya konan görüşler, sanatın belli dallarının gelişmesinin önünde engel olarak durmuştur.

Aynı şekilde estetiğin temel kavramlarından güzellik, doğruluk, iyi-hoşyüce iliş̧isi de Islâm düşüncesi içinde tartışıla gelmiştir. Buna rağmen lise DKAB programları ve ders kitapları sanatı felsefenin soruları kapsamında değil, tarihsel çizgide üzerinde konu edinmeyi tercih etmişlerdir.

Konu, lise 3. sınıflarda "Türk-İslâm Kültür ve Uygarlığı" ünitesi altındaki "Müslüman Türklerde Sanat ve Edebiyat" dersi altında işlenmektedir. Estetiğe ilişkin sadece bir paragraflık bilgi, İslâm düşüncesindeki birikimi yansıtmadığı gibi ögrenci üzerinde konu ile ilgili bir yaklaşım geliştirmede yetersiz kalmaktadır ${ }^{11}$. Ders kitabında şunlar söylenmektedir:

"Kur'ân ve hadisler ışı̆̆ında incelendiğinde, estetik düşüncenin Islâm'ın kendi yapısı içinde var olduğunu görüyoruz. Cenabı Hak Kur'ân'da namaz

${ }^{50}$ Çelik-Bal, Felsefe Ders Kitab̆, 117.

51 Çetin-Öcal-Algül, 88-95. 
kılınırken güzel elbiseler giyilmesini, özellikle camilere temiz ve tertipli bir kıyafetle gidilmesini emreder; gökyüzünü kandillerle güzelleştirdiğini belirtir. Sevgili peygamberimiz de "Allah güzeldir, güzelliği sever" buyurur."52

Ders kitabı daha sonra ise sanat ve edebiyatta Müslüman Türkler'in katkılarının tarihçesi ile konuya devam etmektedir. Buradaki anlatımlar, öğrencilere resim ve heykel gibi alanlarda Müslüman sanatçıların yokluğunu ve İslâm dünyasındaki sanata karş̧ şiddet hareketlerini açıklamada yeterli olmamaktadır (Sanata tüküren veya heykelleri kırıp döken anlayışlar gibi...).

\section{Din Felsefesi}

Din felsefesi, din üzerine felsefî olarak düşünmek; dinîn kendisini, temel kavramlarını ve savlarını soruşturmak olarak anlaşılır. Konusu belirli bir din değildir, din olgusunun kendisidir. Ancak farklı bakış açılarını tartışan din felsefesinin temel sorularına (Tanrı'nın varlığı sorunu, evrenin yaratılışı ve vahiy olanaklı mıdır? soruları) her dinîn kendine özgü bir cevabı olacaktır. Bununla birlikte Tanrı'nın algılanışı üzerine de fikir verecek argümanları bulunmaktadır. DKAB, öğrencilerin felsefe derslerindeki tartışmalar üzerinde sağlıklı bir anlayış geliştirebilmesi için bu soruların cevaplarına yönelik İslâm düşünürlerinin dinsel argümanlara dayalı olarak üretimlerinden haberdar etmek durumundadır. Burada Tanrı'nın varlığ sorunu ve evrenin yaratılışına ilişkin sorular "varlık felsefesi" kapsamında değerlendirildiğinden yeniden incelenmeyecektir. Ancak şunu söylemeliyiz ki ders kitaplarında "Allah" kavramı ile ilgili olarak anlatımlar klasik sıfatlar kalıbı içinde yapılmış, öğrenciler üzerinde Kur'ân'daki Allah anlatımını yansıtamamıştır. Bu eksiklik felsefe öğretiminde Tanrı'nın varlığını kabul eden görüşlerdeki farklı Tanrı anlayışları içinde öğrencinin, Allah kavramını nereye oturtacakları konusunda sorunlar oluşturabilmektedir.

Felsefe öğretiminde konu edilen sorular açısından lise DKAB programlarını ve ders kitaplarını incelemeye çalışalım. Bu incelememizde din felsefesindeki "vahiy olanaklı mıdır? ve ruh ölümsüz müdür? sorularını temel alacağız çünkü din felsefesinin diğer soruları açısından inceleme, önceki bölümler içinde yapılmıştır.

Lise DKAB öğretiminde vahiyle ilgili olarak direkt bir konu ayrılmamıştır. Gerek diğer dinlerin anlatıldığı gerekse de İslâm dinînin inanç esaslarına ilişkin bilgilerin verildiği ünitelerde vahye ilişkin hiç bir bilgi bulunmamaktadır. Halbuki dinsel yapıları diğer felsefî sistemlerden ayıran en önemli özellikleri vahye dayalı olmalarıdır. Buna ilaveten dinler arasındaki farklılıkların anlaşılmasında vahye ilişkin anlayışlarının ortaya konması önemli oranda yardımcı olacaktır. Lise 3. sınıf programı içerisinde kitap inancından bahsedilmesine rağmen vahiyle bağlantısı kurularak açılamalarda bulunulmamaktadır. Halbuki felsefe öğretimi çerçevesinde din felsefesi konusu altında vahyin imkânı tartışılmaktadır ve bu tartışmaların

52 Agy. 
din öğretimi çerçevesinde dinîn vahiyle ilgili görüşlerinin öğretim çevresine girmesi gerekmektedir.

\section{Bulgular Ve Yorum}

Araştırma, Üniversite sınavlarına hazırlık amacıyla Bingöl ilindeki bir dershaneye devam eden lise son sınıf ve mezun durumdaki öğrenciler üzerinde yapılmıştır. 2001-2002 öğretim yılının II. yarı yılından itibaren sözel ve eşit ağırlık gruplarına dâhil 6 şubedeki 180 öğrenciye felsefe dersleri kapsamında haftada 6 saatlik bir çalışma süreci başlatılmış, felsefenin soruları düzenli bir şekilde tartışılmıştır. İlaveten etüt saatlerinde bu sorular daha küçük öğrenci gruplarıyla yoğunlaştırılmı̧ görüşmelerde devam ettirilmiştir. Bu tartışmalarda edinmiş olduğumuz gözlemler, sistematik bir araştırma ihtiyacını ortaya çıkarmıştır. Bu ihtiyaç çerçevesinde felsefe derslerindeki tartışmalara katılan öğrencilerin istekli olanlarından 100 kişilik bir gruptan yarı yapılandırılmış görüşme formu yoluyla veriler toplanmıştır. Bulgular, bu görüşme formundaki bilgilere dayanmakla birlikte bulguların yorumlanmasında çalışma grubumuzla yaptığımız tartışmalardaki gözlemlerimizden de yararlanılacaktır.

\section{Kişisel Özellikler}

Öğrencilerin kişisel özellikleri değişken olarak alınarak onlara bağlı yorumlar yapılmayacağından çalışma grubumuzun genel özelliklerini ana hatlarıyla tanıtmak amaciyla sadece cinsiyet ve mezuniyet durumlarına ilişkin bilgiler alınmıştır.

Tablo 1. Araştırnna Grubunun Cinsiyetlere Göre Dağılımı

\begin{tabular}{|l|l|}
\hline Cinsiyet & Sayı \\
\hline Erkek & 63 \\
\hline Kiz & 37 \\
\hline Toplam & 100 \\
\hline
\end{tabular}

Tablo 2. Araştırma Grubunun Mezuniyet Durumların Göre Dağılımı

\begin{tabular}{|l|l|}
\hline Mezuniyet Durumu & Sayı \\
\hline Mezun & 69 \\
\hline Lise Son Sinıf Öğrencisi & 31 \\
\hline Toplam & $\mathbf{1 0 0}$ \\
\hline
\end{tabular}

Tablolardan da anlaşılacağı gibi araştırma grubunun çoğunluğunu erkek öğrenciler (63), diğerlerini ise kız öğrenciler oluşturmaktadır(37). Bu öğrencilerin önemli bir bölümü lise mezunu öğrencilerdir(69). Felsefe öğretimini ve din öğretimini tamamlamışlardır. Bu öğrencilerin çoğunluğu oluşturması, yapılan tartışmalarda alt yapıları bulunmaları nedeniyle katılımın yüksek 

Ve Din Kültürü-Ahlak Bilgisi Öğretimi İlişkisi

olması sonucunu doğurmuştur. Geriye kalanlar ise (31) lise son sınıf öğrencisidir.

\section{2. Öğrencilerin "Bilimsel Bilgi-Felsefî Bilgi ve Dinsel Bilgi”" Üzerine Düşünceleri}

Felsefe öğretimi çerçevesinde bu üç bilgi türünün birbirleriyle ilişkisinin nasıl incelendiğini görmüştük. DKAB öğretimi içinde ise dinîn bilgiye bakışının yeterince açık bir şekilde incelenmediği sonucuna ulaşmıştık. Burada ise öğrencilerin kendilerinin aldıkları eğitim ve etkilendikleri diğer faktörler çerçevesinde bu üç bilgi türüne karşı nasıl bir tavır geliştirdiklerini ortaya koymaya çalışacağız. Bu açıdan sırasıyla öğrencilerin bu bilgi türlerini nasıl anladıklarını yoğunluk sırasına göre inceleyip değerlendirmeye çalışacağız.

\section{a. Felsefe Bilgisi}

-Sorgulayıcıdır, araştırıcıdır, sorular daha önemlidir, merak ve şüpheye dayanır, çözülemeyen sorulara yoğunlaşır, metafizik sorularla ilgilenir (37), Eleştireldir (25), Özneldir (Subjektiftir) (25), Eleştiriye açıktır (13), İspatlanamaz (4), Kesin bilgiye ulaşma çabası değildir, sonuçları da kesin değildir (7), Değişkendir (4), Akıl yoluyla elde edilen bilgidir, özgür düşünmedir, düşünmeye dayalıdır, düşünme etkinliğini geliştirir, düşüncelerin yargılanmasıdır, yeni düşünceler ortaya koyar (11), Deney ve gözleme dayanır (3), Nesneleri ve evreni bütünsel olarak inceleyen bilgidir (5), Evrenseldir, Genel geçerliliği yoktur, Olması gerekeni inceler, Mantık ve gözleme dayanır, Hayata bakış açısını verir, Bilimsel sonuçları eleştirir, Yığılarak ilerler, Dogmatiktir, Evreni inceleyen bilgidir, Doğru bilginin mümkün olup olmadığına yanıt verme çabasıdır, Neyin doğru, neyin yanlış olduğunu araştırır, değer koymaya çalışır (2), Tüm dünyayı içine alır, Çürütülebilir

\section{b. Bilimsel Bilgi}

-Deney ve gözleme dayalıdır, araştırma sonucu elde edilir (47), Kanıtlanabilir, Kesin olan bilgilerdir (25), Nesneldir (Objektiftir) (21), Olgusaldır, somut bilgidir (12), Genel geçer olduğundan tartışlamaz, evrenseldir (12), Çürütülebilir (7), Eleştiriye açıktır (6), Neden-sonuç ilişkisine dayanır (5), Birikimli ilerler (4), İhtiyaçlar karşısında ortaya çıkar, Evreni, toplumu ve insanı araştırma konusu yapan bilim dalıdır, Hayatımızda her zaman değişip ilerleyen ve gelişen bir faktördür, Merak ve şüpheye dayanır, Kesinlik yoktur, Şüphecidir, Değişmeyen bilgidir, Varlığ yoktur.

\section{c. Dinsel Bilgi}

-Dogmatiktir, eleştiri söz konusu değildir, sonuçlar kesin ve değişmezdir, değişmeye kapalıdır, inanç sistemlerinin temeli olduğu için tartışılamaz (53), Inançlara dayalıdır, kanıtlanmasına ihtiyaç yoktur (21), Kaynağı 
İlahîdir, Tanrı tarafından insanlara peygamberler aracılı̆̆ı ile gönderilen bilgidir, Tanrı (Allah) tarafından bizlere gönderilen kitaplar aracılığı ile gelen bilgidir (26), Tanrı ile kul arasındaki ilişkiyi incelemektedir (5), Konusu Tanrı'dır, Tanrı'nın var olup olmadığını sorgular (7), Tanrı'yı kanıtlamak için kullanılır (3), Yaşamı düzenleme amacı vardır (2), Eleştiriye açıktır (2), Özneldir (2), Suje-obje arasındaki ilişkinin inanç yoluyla kurulduğu bilgidir (2), Varlığın oluşumu ve hayatımıza etkisini inceler (2), Dinî kaynaklara göre yorumlanarak elde edilir (2), Belli sınırlarda düşünceye yer vardır, Allah'la kul arasındaki bilgidir, Dinî yaşama biçimidir, Dinîn üzerinde üretilen bilgidir, İnsana din açısından yaklaştığından uygundur, İnsanların soyut bir şekilde kabul ettikleri ve onayladıkları bilgidir, Mantık ve kalp arasında oluşur, Olması gerekeni inceler, Kurallar ve yaptırımlardan oluşur, Ahlâkî erdemdir, Maddeye dayanmayan zihinde var olan gerçekleri ortaya koyar, İnsanın örf ve âdetlerine uygun olayları kabullenmeli ve kendi görüşlerine uymayanları ise dışlamalıdır, Her şey doğru kabul edilir, Genel geçerdir, Objektiftir, Akla dayanır, Vahye dayanır, Yaratılış nedenlerini inceler, Sorgulayarak Tanrı'ya ulaşılır, Düşüncelerin yargılanmasıdır, Değişik dinlerin bir araya gelerek hangisinin doğru olduğunu bulma çabasının sonucudur, Nesneldir, Sonuçları değişmezdir, Sorular yoktur.

Soru, ögrencilere "Felsefe Bilgisi, Bilimsel Bilgi ve Dinsel Bilgi arasındaki farklar üzerine düşündüklerinizi yazını" şeklinde sorulmuştur. Verilen cevapların incelenmesinden de anlaşılacağı üzere öğrencilerin önemli bir bölümünün verdiği cevaplar, felsefe öğretimindeki amaçlara paralel olarak hazırlanan ders kitaplarının verdiği bilgilerle örtüşmektedir. Öğrenciler bu üç bilgi türü arasındaki farklılaşmanın başladığı noktaları ve hangi bilgi türünün hangi alanda kullanıldığı üzerine düşünmede zorlanmaktadır. Sınıf içinde yapılan tartışmalarda kendi görüşlerini rahatlıkla dile getirirken, görüşme formunun doldurulmasındia aynı rahathı̆̆ı sergileyememişlerdir. Yine de verilen cevaplarda sınıfta yapmış olduğumuz tartı̧̧maların izlerini gözlemlemek mümkündür. Öğrencilerin bu konularda söylediklerinden ilgi çekici olanlarından bir kısmını aşağıya aldık:

“...Felsefe bilgisi sorgulayıcıdır, araştırıcıdır. Örneğin insanın var oluşuna, Tanrı'nın varlığına dair dinsel bilginin dayanaklarını felsefe kabul etmeyebilir, bunu araştırır. Yani dinsel bilgi her şeyin Allah'tan geldiğini ve tekrar Allah'a döneceğini söyler, buna kanit olarak da dinsel kaynakları gösterir. Bilimsel bilgi ise bunları deney yoluyla kanıtlamaya çalışır..."

“...Dinsel bilgi ise Tanrı tarafından gönderilen hadis, kutsal kitap ve bunun gibi şeylerden dolayı diğer iki kavramdan ayrılır ve sonucu asla değişmez, kesindir..."

"...Dinsel bilgi inanç sistemlerimizin temeli olduğu için tartışmıyoruz, bilimsel bilgi genel geçer olduğu için tartışmıyoruz. Bu yưzden felsefî bilgi benim sempatimi çekmiştir..."

“...Felsefe bilgisi soruların, neyin nereden geldiği, nasıl var olduğu gibi şeylerin peşindedir. Her zaman soru sorar ve cevaplar verir, sorular daha 
önemlidir. Cevapları ise herkes kendine göre verir. Sonuçları ise kesin değildir. Dinsel bilgi kesindir. Allah tarafından peygamber aracılığı ile Kur'ân'ı Kerim'e yazılmış ve bizlere aktarılmaktadır. Bazı şeyler K. Kerim'de olmayabilir. Bunları da karışımızdakine var oluşuna inandırırız. Bilimsel bilgi kolay elde edilebilir. Deney ve gözleme dayandığı için herkese kolayca inandırabiliriz ve kesindir..."

“...Dinsel bilgiye de daha önceki insanların yaptıkları ibadetleri biz de yapmak zorundayız. O zamanla ilgili yazılmı̧ olduğu kitaplara inanıyoruz..."

“...Felsefe bilgisi, düşünme ve eleştiriye dayalıdır. Oysa dinsel bilgi Tanrı'ya olan inanç ve yaşadığımız değerlerle ilgilidir. Bilimsel bilgiyi ben dinsel bilgi ile bir arada düşünemiyorum. Çünkü bilimsel bilgi evrenin oluşumu vb. metafizik konuları Tanrı'yla bir arada incelemiyor ve bu beni hep çelişkiye düşürmüştür. Felsefî bilgi, bilimsel bilgiyi hem destekler, hem de eleştirir, yani birbirleriyle ilişkileri vardır..."

“...Felsefe bilgisi hayata bakış açısını; dinsel bilgi varlığın oluşumunu ve hayatımıza etkisi, bilgi hayata insanların çevresini, kendisini bilmek ve gereksinimini duyduğu hayata kendisine tutulan 1 şı doğrultusunda ilerlemesi için bilmesi gerekeni, bilmek istemesiyle doğar..."

“...Felsefe bilgisi, benim kendi düşüncemi oluşturan ve temellendiren ve etrafımdaki nesneleri tanımlamak için bir çok soru sormamdır. Eleştiriyorum, düşünüyorum. Kesin sonucu olsa bile arkadaşım düşüncemi çökertebilir. Önemli değil, çünkü ben kendi düşüncemi belirtmiş oluyorum. Yani öznel olan bir bilgidir. Şüphe her yerde gereklidir. Doğru bilgiyi analiz etmemde yardımcı olur. Gördüklerimi anlamlandırmam buna bağlıdır. Dinsel bilgi hiç bir şekilde eleştiriyi kabul etmez. Yani dogmatiktir. Bu bilgiler herkes için geçerlidir. Sonuç kesindir. Bilimsel bilgi de nesneldir. Evrenseldir, genelleyicidir. Kesindir, eleştiriyi belirli bir noktadan sonra kabul etmez..."

“...Felsefî bilgi öznel, eleştiriye açık, doğruluk derecesi tartışılabilir, başkaları tarafından çürütülebilir bir bilgidir. Dinsel bilgi, kaynağı ilahî olan, doğruluk değeri tartışılamaz ve kesin olan, eleştiriye kapalı bir bilgidir. Bilimsel bilgi ise olgulardan yola çıkan, tam bir kesinlik içermeyen, ortaya çıkan olgunun olumlu ve olumsuz veya olumlu yönü çıkınca sonucunun değişmesi mümkün olan bir bilgidir, birbirlerinden ayrılırlar..."

“...Felsefî bilgi, dinsel bilgi ve bilimsel bilgi birbirlerinden uzak bilgidir. Bunlar birleşemezler..."

“...̇̀nsanın dinîne bağlı olup olmadığını, inançlı olup olmadığını araştıran bilgi çeşididir..."

“...Dinsel bilgi ise Allah tarafından peygamberler aracıllı̆̆ ile insanlara verilen bilgidir..."

Öğrencilerin felsefî bilgi, bilimsel bilgi ve dinsel bilgi üzerinde söylediklerini incelediğimizde felsefi bilgi ve bilimsel bilgi de ders kitabında verilen özelliklerin üzerinde önemli oranda uzlaşıldığı gözlenmektedir. Örneğin felsefî bilgide sorgulayıcı olması, araştırıcı niteliği, soruların daha fazla 
önem taşıması, eleştirel olması ve eleştiriye açık olması öğrencilerin tamamına yakını tarafından dile getirilmiştir. Bilimsel bilgide de deney ve gözleme dayalı olması, nesnel olması ve olgusal olması gibi özellikler öğrencilerin önemli bir kısmı tarafından benimsenmiştir. Halbuki dinsel bilgi üzerine öğrencilerin ifadeleri ders kitabındaki dogmatik, eleştirinin söz konusu olmaması, sonuçların kesin ve değişmez olması ve inançlara dayalı olmasının dışındakiler; hem felsefe ders kitabındaki bilgilere direncin bir göstergesi olduğu gibi, aynı zamanda dinsel bilgi kavramına ilişkin sağlıklı bir anlayışın geliştirilemediğini ortaya koymaktadır. Zira öğrenciler, dinsel bilginin kaynağının İlahî olduğunu söylerken ders kitabında olmayan bir düşünceyi ortaya koymaktadır. Bunun dışındaki düşünceler de öğrenciler arasında bir uzlaşma bulunmamakta; dinsel bilgi ile ilgili anlayış, oldukça geniş bir yelpazede farklılaşmaktadır.

\section{3. Öğrencilerin "Bilginin Değeri Nedir? Doğru Bilgi Mümkün müdür? Doğru Bilgi Mümkünse Ölçüsü Nedir?" Soruları Üzerine Düşünceleri}

Bilgi kuramının temel sorularının bir kısmı da bilginin kaynağına ilişkindir. Bilgilerimizin kaynağı nedir? Bilgimiz akla mı, deneye mi, yoksa sezgiye mi dayanmaktadır? gibi sorular bunlara örnektir. İkinci bir kısmı ise bilginin değeri ile ilgili sorulardır. "Var olanların doğru bilgisi var mıdır? Varsa bunları bilmek mümkün müdür? Bilgimiz kesin bir bilgi midir? Bilgilerimiz doğru ise bunun ölçütü nedir?" soruları da bilginin değeri altında sırlanmaktadır. Elbette bu sorular dinsel referanslarla da cevaplandırılabilecek ve cevaplandırılmış sorulardır. Benim burada öğrencilerden bu sorular üzerinde düşüncelerini aktarmalarını istemekten amacım; onların bu soruları cevaplandirırken dinsel materyallere ne derecede atıf yapabildiklerini görebilmekti. Ancak öğrenciler, kendilerine yönelttiğim sorular içinde en fazla burada zorlandılar ve elle tutulur yorumlar yapılabilecek malzeme sunamadilar.

Bilginin değerine ilişkin sorularla irtibat kuramadılar. Zira cevaplarda sadece 12 kişi doğru ve yanlış şeklinde bir ayırım, 2 kişi de iyi-kötü şeklinde bir ayırımla yetindi. Aslında benim sorularımın diğer ikisi de, bilginin değerini açımlayan alt sorı niteliğinde idi. Doğru bilginin imkânı konusunda 55 kişi mümkündür cevabını verirken, 23 kişi ise mümkün olmadığı sonucuna ulaştı. Bunların gerekçeleri ise bireysel farklılıklar ve zamanın değişimi idi. Doğru bilginin ölçütü konusunda ise şu sonuçlar alındı:

\section{Doğru Bilginin Ölçüsüi Nedir?}

-Akıl, Algı (26), Bilim, Araştırma (29), Fayda (15), Tanrısal Kaynaklar, Din, Peygamberler, Kutsal Kitaplar (18)

Öğrencilerin doğru bilginin ölçüsü olarak ortaya koydukları rasyonalizm (akla dayanan bilgi doğru bilgidir), emprizm (deneye dayanan bilgi 

Ve Din Kültü̈r̈̈-Ahlak Bilgisi Ögretimi İlişkisi

doğru bilgidir) ve pragmatizm (fayda sağlayan bilgi doğru bilgidir) dışında dinsel kaynakları da dikkat çekici bir şekilde belirtmeleri ilginçtir. Belki de benim burada soruyu sorma biçimimden kaynaklanan eksiklik, öğrencilerden dikkat çekici bulguların elde edilmesine engel olmuştur. Çünkü öğrencilerin serbest bir şekilde yazdıkları ifadelerde ilginç yaklaşımlar ortaya çıkabilmektedir:

“...Doğru bilginin mümkünlüğü ise farklıdır. Çünkü farklı bilimler ve buna bağlı olarak doğruluğu değişkendir. Örneğin matematik bilgisi kesindir. Çünkü dünyanın her tarafında iki kere iki dört eder. Ama biz bilginin metafizik boyutuna bakarsak evren sonsuz mudur? sorusuna verilen cevaplar farklıdır ve doğru olanı bilmek mümkün değildir..."

“...Doğru bilginin olmadığını savunuyorum. Çünkü bizim yaratılışımızda ve evrenin yaratılışındaki sırrı çözemediğimiz için doğru bilgiye sahip olamayız..."

“...Doğru bilgi mümkündür, zira Allah'ın göndermiş olduğu belgelerden, bilim adamları ve peygamberlerden alınan bilgi doğrudur..."

"...Insanları etkileyebileceği ve insanlar belli bir yol için ışı oluyorsa o bilgi değerlidir. Bilgi, dünyadaki insanların kaynaklık ettiği bilgi ve bazı dış güçlerin çeşitli yollarla gönderdiği bilgiler vardır. Bilgi, insanların kendi çıkarlarına yönelttiği bir araçtır. Araç olduğu için de doğruluğundan söz etmek mümkün değildir. Çünkü iki yüz yıl önce doğruluğu savunulan bilgi bugün çürüyor ve doğruluk derecesi yok oluyor..."

“...Doğru bilgi bana göre mümkün değildir. Çünkü benim baktığım kaleme ayrı yönden bakan başkası kalemi benim gördügümmden farklı görür ama kalem aynıdır. Bilgi zamanla değişebilir. Atom bombası yapıldığında kimse ne kadar zararlı bir şey oldugunun farkında değildi. Ama sonra bu görüşlerinin yanlış olduğunu anladılar. Bilgi bana göre sürekli değişim içindedir..."

\section{4. Öğrencilerin "Varlığın Kökeni”’ Konusundaki Düşünceleri}

Varlığın kökeni, varlık felsefesinin temel soruları altındaki "varlığın temeli nedir" sorusuna karşılık gelmektedir. Felsefe öğretimi bu soruyu, varlığı oluş olarak kabul edenler, varlığı idea olarak kabul edenler ve varlığı madde olarak kabul edenler ve varlığ fenomen olarak kabul edenler başlıkları alında tartışmaktadır. Öğrencilerin bu tartışmalar içinde kendi görüşleri aşağıdaki sıralanmıştır:

-Tanrı (30), Allah (23), İdealar (3), Metafizik (3), Çeşitli unsurlar (3), Madde (3), Insan düşüncesi (2), Madde-ruh, Değişim, Ruh.

Öğrencilerin cevaplarının en az farkhılaştığı soru, varlığın kökenine ilişkin olandır. Cevap verenlerin önemli bir bölümü, varlı̆̆ın kökenini Allah veya Tanrı olarak isimlendirmişlerdir. Diğer cevaplar ise felsefe öğretiminde varlık felsefesi kapsamında ortaya çıkmış olan cevaplardır. Halbuki varlık felsefesi kapsamında, dinsel cevaplar hiç konu edilmemiştir. Dinîn varlıkla ilgili görüşleri yetersiz bir şekilde de olsa din felsefesi altında tartı- 
şılmaktadır. Öğrencilerin görüşleri derinliğine incelendiğinde aslında Tanrı cevabının da arkasında İslâm'daki Allah kavramıyla örtüşme bulunduğu görülmektedir:

“...Varlığın bir yaratıcısı vardır. O da Allah'tan gelmiştir. Mesela Allah istedi dünya oldu. Örneğin insan topraktan yaratıldı..."

“...Varlığın kökeni Tanrı'dır. Çünkü varlık doğar, büyür, ölür. Bunların gerçekleşmesini sağlayan tek bir etken vardır. O da Tanı'dır. Her şey O'ndan geldi ve O'na dönecektir..."

“...Varlığın kökeni konusunda eskiden beri tek Tanrı düşüncesi vardır. Bunun aksi ispatlanamaz, ispatlanamayacaktır..."

“...Varlığın kökeni Tanrı'ya dayanmaktadır. Bundan dolayı her varlığın başlangıç noktası vardır. Bu başlangıç noktası ise Tanrı'nın isteği doğrultusunda gerçekleşmektedir. Bu yüzden varlığın kökeni Tanrı'dır..."

“...Varlık, var olan,yaşamakta olan, kendi değer ve yargılarıyla ve bu ölçüler içinde kendinî idame ettirendir. Varlığın kökeni yaratılıştır, temeli yaratılmaktan gelir. Yaratılmak, yaratmak inanan ve inançlı insanlar için Allah'tır..."

“...Bütün varlıkları yaratan Allah'tr...”

“...Varlığın kökeninin Yüce Rabbimiz tarafından yaratılmış olduğunu biliriz..."

“...Varlık, Allah'ın düşünmesi üzerine ortaya çıkmıştır. Kökeni Allah'a dayanır. Nasıl bir iğneyi yapan bir fabrika varsa diğer varlıkları Yaratan bir kişi vardır. O'da Tanrı'dır..."

“...Varlığın kökeni Tanrı’dır. Çünkü yaratılanlar kendi başına hiç bir şey olmayacağına, ömeğin varlığın kökeni su olsaydı, peki suyu kim yarattı? Bu nedenle varlı̆̆ın kökeni üstün bir varlık olan Tanrı'dır..."

“...Varlığın kökeni bence Tanrı'ya (ALLAH'A) dayanır...”

“....Bazıları varlığın tesadüfler sonucu oluştuğunu ya da maddeye dayandığını ileri sürer, bu görüşlere katılmıyorum. Çünkü varlık öyle bir yaratılmış ki tesadüf olması imkânsız. Maddeye de dayanmıyor. Çünkü madde de bir varlıktır ve onu da var eden bir güç vardır. Bence insanlar ne kadar düşünürse düşünsünler varlığın temelinde Tanrı'nın olduğuna inanacaktır..."

“...Varlığın kökeni ve insanların yaratıcısı Allah'tır, insan O'nun yaptıklarına bakınca O'na kendinî biraz daha yakın hissetmektedir..."

“...Varlığın kökeni hakkında kararsız ve şüpheci düşünceler içindeyim. Çünkü ilk varlık Hz. Adem'dir. Ama bazı teorilere göre ilk insanın yani ilk varlığın maymundan türediği ileri sürülüyor. Düşünüyorum da kesinlikle ilk varlık ve ilk canlı $\mathrm{Hz}$. Adem'dir. Ama neden bazıları gereksiz şeylerle yok varlığın kökeni maymunnuş, yok başka bir şeymiş ya da çamurdan ilk varlığın meydana geldiğini ileri sürerek tüm insanların kafasını karıştırıyorlar. İşte gereksiz aldatmacalarla tüm insanların kafasında şu soruyu bırakıyorlar: Gerçekten biz maymun soyundan mı geldik? İşte hocam ben de size "neden bu insanlar gereksiz şeyler ileri sürüyorlar?" sorusunu sormak istiyorum..." 
“...Varlığın kökeni konusunda düşünebiliriz ki...şüphesiz ki her şeyi ALLAH yaratmıştır. Hiç şüphem yok. İnancım tam ve sonuna kadardır. Ben gelip burada yok varlık sudan, yok bilmem ateşten, yok bilmem neden oluşmuş desem inandırıcı gelmez. Bir tek yaratıcı var, O'da Allah-u Teala'dır. Bilmem anlatabiliyor muyum!..."

“...Bu dünyayı yaratan Tanrı, dünyayı bence kendi yarattığı varlıkları kendinden uzaklaştırarak onların düşünce ve hareketlerini izlemek, bunu yaparken de boş zamanlarını değerlendirmek, yani Tanrı'nın insanları yaratmasındaki amaç, boş zamanını değerlendirmek, uğraşacak bir şeyler bulmaktır. İnsan gereksiz bir varlıktır. Havayı kirletir, doğayı bozar, hep yıkıcıdır. Hiç yapıcı değildir. Tanrı'nın yarattığı varlıklar içinde yalnızca insanlar kendi cinsini öldürür..."

“...Varlık kendiliğinden olmamıştır. Felsefe varlığın yoktan var olmadığını söylüyor. Bu bilgi kesinlikle yanlıştır. Çünkü bu düşünce Allah'ı inkâr etmektedir. Bu düşünceler komünistlere aittir. Bu soruda maddenin evrensel olduğunu söylüyor. Ancak bu yanlıştır...fakat bunlar kendiliğinden bir ev yapamaz. Bunları yapan biri olmalıdır. İşte madde evrensel değildir. Dolayısıyla maddeyi de yapan Allah'tır..."

Öğrencilerin söylediklerinden ve bizim gözlemlerimizden varlığın kökeni konusunda öğrencilerin Tanrı-Allah kavramına yöneldikleri sonucu gözlenmektedir. Ancak bu kavramı algılamalarında bazı farklılıklar gözlenmektedir. Ögrencilerin dersler sırasında farklı felsefî görüşlere dinsel endişelerle zaman zaman şiddetli bir şekilde direnç göstermeleri burada verdikleri cevaplara da yansımıştır. Öğrencilerde biraz da eğitim sistemimizin katkısıyla dersin içeriğinde verileni olduğu gibi alma alışkanlığı bulunmaktadır. Tartışma ve eleştiri geleneği bulunmamaktadır. Dolayısıyla geleneksel görüş ve kanaatlerle zıt düşünceler ders ortamında gündeme geldiğinde şiddetli bir direnç oluşmaktadır. Bunların çeşitli anlama biçimleri olduğuna ilişkin açıklamalar yapıldıktan sonra konuya devam etmeye uygun ortam oluşabiliyordu. Farklı liselerde görev yapan felsefe öğretmenleriyle bu konuyu görüştügümde kendilerinin inançla ilgili tartışmaları doğurması muhtemel felsefe konularını atladıklarını ve hiç işlemediklerini ifade etmişlerdir (Örneğin varlık felsefesi).

\section{5. Öğrencilerin “Tanrı'nın Varlığı Kanıtlanabilir mi? Tanrı'nın Varlığına İlişkin Olarak Ortaya Sürülen Kanıtlar Sizce Geçerli midir?” Soruları Üzerine Düşünceler}

Buradaki soru, din felsefesinin temel sorularından "Tanrı'nın Varlı̆̆ı" sorunu altında sorulmuş iki aşamalı bir düşünce sürecini işletmeyi hedeflemektedir. Bu düşünce sürecini başlatmaktaki amacımız, öğrencilerin kendi duruşlarını referanslarıyla birlikte ortaya koyabilme becerilerini ölçebilmekti. Öğrencilerin cevapları aşağıdaki şekilde oluştu: 
Tablo 3: Öğrencilerin Tanrı'nın Varlığının Kanıtlanabilmesi Üzerine Görüşlerinin Dağı̆lımı

\begin{tabular}{|l|l|}
\hline Tanrının Varlığı Kanıtlanabilir & 81 \\
\hline Tanrının Varlığı Kanıtlanamaz & 19 \\
\hline Toplam & 100 \\
\hline
\end{tabular}

Tablo 4: Öğrencilerin Tanrı'nın Varlığının Kanıtlanının Geçerliliği Üzerine Görüşlerinin Dağılımı

\begin{tabular}{|l|l|}
\hline Tanrının Varlığına İlişkin Kanıtlar Geçerlidir & 77 \\
\hline Tanrının Varlığına İlişkin Kanıtlar Geçerli Değildir & 3 \\
\hline Toplam & 80 \\
\hline
\end{tabular}

Öğrencilerin önemli bir bölümü Tanrı'nın varlığının kanıtlanabileceğini ve bu kanıtların geçerli olduğunu düşünmektedir. Felsefe öğretiminde bu konunun dinsel bakış açısından sunumu söz konusu olmamasına rağmen öğrenciler oldukça açık bir şekilde görüşler belirtmişlerdir Şimdi bunları gözden geçirelim:

“...Bence Tanrı'nın varlığı ile ilgili ortaya konan şeyler yeterli değildir, hatta hiç bir kanıt yoktur. Bu zamana kadar Tanrı'nın varlığı kanıtlanmamışsa bundan sonra biraz zor kanıtlanır. Demek ki Tanrı insanların onun varlığını tartışmalarını istiyor ki kanıtlanmasına izin vermiyor (Ömeğin insanlar hep yeni şeyler üretiyor, ürettiği şeyleri görüyor ama üretilen şeylerin onları görecek yeteneği yoktur. Ürettiklerinin faydalı olup olmadığını düşünürler.) Bence biz de hiç bir zaman elle tutulur, gözle görülür bir kanıt ortaya koyamayız..."

“...Tanrı'nın varlı̆̆ı ne bir deney ve ne de bir gözlemle kanıtlanamaz..."

“...Tanrı'nın varlığg kanıtlanabilir. Kanıtı kainatın oluşumudur...”

“....Tanrı'nın varlığı kanıtlanamayabilir. Fakat bütün insanlar tarafından Tanrı'nın var olduğu bilinmektedir. Biz ne kadar kanıtlayabilsek de filozoflar ortaya başka şeyler katarak Tanrı'nın varlığını inkâr ederler. Tanrı olmasaydı insan da olmazdı. Zaten Tanrı'nın varolduğu Kur'ân'da anlatılmaktadır..."

“...Tanrı'nın varlığı kanıtlanamaz, bu konuda sadece fikir yürütülebilir..."

“...Kanıtlanabilir ama inanca dayandığı için geçerliliği tartışmalıdır...”

“....Tanrı'nın varlığı kanıtlanabilir. Insan evrene baktığı zaman evren bir düzen içerisindedir. Bence Tanrı'nın en iyi kanıtı öldükten sonra dirilme olduğu için üstün bir varlık olduğunu anlarız. Tanrı'nın varlığını anlamak inanmak için önce kutsal kitaplara ve tabiata bakmak gerekir..."

“...Tanrı'nın varlığını inkar etmek hiç bir mantığa sığmayacak derecede mantıksız bir olaydır. Yeryüzü ve gökyüzü o kadar güzel bir uyum içerisinde ki bu uyumun tesadüf olması mümkün değildir. Mutlaka bunları yaratan, yoktan var eden olmalıdır. Bir köyün muhtarı, bir iğnenin ustası, bir kitabın yazarı olduğu gibi bu kainatın da bir yaratıcısı vardır. Tanrı'nın varlığı 


\section{Felsefenin Temel Soruları Bă̆lamında Orta Ögretimde Felsefe Öğretimi 265 Ve Din Kültürü-Ahlak Bilgisi Ögretimi Illişkisi}

kanıtlanmıştır. Tanrı'nın varlığını sadece Müslümanlar değil, Hıristiyanlar, Yahudiler bile varlığını inkar etmiyor. Yüce Allah'ımızın, Yaratanımızın aslında Tanrı diye bir adı yoktur. Allah'ın varlığına ilişkin en büyük kanıt Kutsal Kitabımız Kur'ân'ı Kerim'dir..."

“...Kesinlikle kanıtlanabilir. Dünya ve kainata düşünerek bakarsak var olan her şeyde bir mükemmellik ve düzen vardır. Buna en büyük örnek gezegenlerdir. Hiç birinde zerre kadar bir sapma yoktur..."

“...Bence Tanrı'nın varlı̆̆ı metafiziğin alanına girer. Ne felsefe ne de bilim kanitlayamaz..."

“...Insan varlığı hakkındaki bilgileri eleştirdiği zaman ister istemez şüpheye düşer. Yalnız bu şüphe sonuçta insandaki boşluğu dolduran Tanrı'nın da kendisine götürür. Yeter $\mathrm{ki}$ insan düşünmekten ve sorgulamaktan kaçınmasın..."

“...Tanrı, yani Allah'ın varlığının olduğunu sadece çevremize bakarak anlayabiliriz. Örneğin, bir çekirdek topraktan çıkıp ağaç oluyor. Yaprak açıyor. Meyve veriyor. Ve o meyve de örnek olarak elma; elma tatlılığını nereden almış olabilir? Topraktan mı? Mutlaka bunu yapan bir güç olmalı. Bir çekirdek nardan binlercesini meydana getiren nedir..?"

“...Kanıtlanamaz. Allah'ın varlığını düşüncelerimiz ve aklımız yoluyla var olduğunu kabulleniriz. Dünyadaki her şeyin yaratıcısını Allah olarak biliriz. Ağaçların, insanların, hayvanların, canlı ve cansız her şeyin yaratıcısı Allah'tır..."

“...Tanrı'nın nasıl bir fizikî görünüşe sahip olduğunu asla ispatlayamayız ama var olduğunu biliyoruz..."

“...Tanrı'nın varlığı, bizim inancımızda kanıtlanmıştır. Tanrı'nın varlığına dair ortaya sürülen en güzel kanıtlar onun göndermiş olduğu peygamber ve kitaplardır. Biz etrafımıza bile baktığımız zaman Tanrı'nın var olduğunu anlayabiliriz..."

"...Allah In varlığı kanıtlanabilir. Çünkü Yüce Allah insanoğluna akıl ve mantık vermiştir. Kişi iradesini kullanarak Allah'ın varlığını görebilir. Tabiata bakarak bunların bir yaratıcısı olduğunu görebiliriz ve Yüce Allah biz insanoğluna bir çok peygamber göndermiştir. Kur'ân-1 Kerim bunun en güzel örneğidir..."

\section{6. Öğrencilerin "Evrensel Ahlâk Yasası Mümkün müdür? Eğer} Mümkünse Ahlâk Yasalarının Kaynağı Sizce Nedir” Soruları Üzerine
Düşünceleri

Felsefe ögretiminde ahlâk felsefesi kapsamında ağırlıklı olarak işlenen konu evrensel bir ahlâk yasasının olup olmadığı sorunudur. Biz de bu soruyla öğrencilerin tartışmalar içindeki duruşlarını ve referanslarını nasıl ortaya koyduklarını ögrenmeye çalıştık. Şimdi bu konudaki öğrenci görüşlerini görmeye çalışalım. 
Tablo 7: Ögrrencilerin Evrensel Bir Ahlâk Yasasının Imkânı Konusundaki Görüşlerinin Dağılımı

\begin{tabular}{|l|l|}
\hline Evrensel Bir Ahlâk Yasası Mümkündür & 43 \\
\hline Evrensel Bir Ahlâk Yasası Mümkün Değildir & 57 \\
\hline Toplam & 100 \\
\hline
\end{tabular}

\section{“Mümkündür" Cevabını Verenlere Göre Ahlâkın Kaynakları}

- Toplum, Çevre, Gelenek-Görenek (35), İnsan-Birey (16), Din, Allah, Tann, Vahiy (17), Haz (4), Evren (2), Ortak Akıl, Devlet

Öğrenciler ahlâkın kaynağını din olarak göstermeye, gerek felsefe öğretiminde gerekse din öğretiminde bahsedilmesine rağmen yeterince eğilim göstermemişlerdir. Öğrenciler için önemli oranda Ahlâkın kaynağı din dışı unsurlarda aranmaktadır. Daha sağlıklı değerlendirmeler yapabilmek iç̧in ögrencilerin söylediklerine yakından bakalım:

“...Bence mümkündür. Eğer mümkün olmasa idi dünyada ahlâk, adalet, eşitlik diye kavramlar ortaya çımmazdı. Güçlü olan her zaman güçsüzü ezecektir. Kul hakkı diye bir şey olmazdı..."

“...Evrensel ahlâk yasası mümkündür. Ahlâk yasalarının kaynağı düşüncelerdir. Çünkü düşünerek olması gereken yere varmak hiç de zor değildir..."

“...Evrensel ahlâk yasası mümkündür. Insanlar fiziken ve ruhen aynı yapıdadır. Mantık kurallarıyla bilimsel bilgiyi kabullendiği gibi ahlâk kurallarını da kabul edebilir..."

“...Evrensel ahlâk yasası içinde bulunulan duruma göre değişir. Bu şekilde evrensel bir ahlâk yasası olamazdı..."

“...Evrensel ahlâk yasası mümkündür. Çünkü bütün insanlarda akıl ve mantık vardır. Neyin iyi neyin kötü olduğunu iradesiyle bulabilir. Bence ahlâk yasasının kaynağ ${ }_{1}$ dindir. Çünkü din bize neyin kötü neyin iyi olduğunu açıkça söyler..."

“...Günümüz için ahlâk yasası mümkün değildir diyorum. Çünkü bence ahlâk yasasının kaynağı dindir. Ama kimse dine saygı bile duymuyor. Kimse kimseyi çekemiyor, herkes menfaati için çalı̧̧ıyor. Bence ahlâk, güzel olan davranışlardır. Oysa ki günümüzde her türlü suç işlenmektedir. Siz de bana ahlâk yasasının olup olmadı̆̆ını soruyorsunuz. SİZCE?.."

"...Evrensel ahlâk yasası bence yoktur. Çünkü olursa özgürlük diye bir şey olmaz..."

“...Evrensel bir ahlâk yasasından söz edilemez. Bir toplumda ahlâka uygun olan bir davranış, diğerine göre ahlâk dışı olabilir. Yani topluma göre değişir. Her toplumun kendine göre bazı ahlâk kurallanı vardır..."

"....Evet mümkündür. Bana göre din ve Yaratıcı olan Allah'ın koyduğu buyruk ve emirler onun kaynağıdır..."

“...Evrensel ahlâk yasası mümkündür. Fakat bazı toplumlarda bu değişiklik gösterebilir. Mesela biz bir ineği yiyebilirken Hint toplumu ona Tanrı olarak tapar, bu yüzden de ahlâk yasasının kaynăg 1 toplumun kültürüdür..." 

Ve Din Kültürü-Ahlak Bilgisi Ögretimi İlişkisi

“...Evrensel ahlâk yasasından söz edilemez. Çünkü ahlâk yasası toplumdan topluma hatta kişiden kişiye göre değişir. Başkasına göre ahlâklı olan bir davranış bana göre ahlâklı olmayabilir. Kişinin özgür davranışına ve düşüncesine göre değişebilir. Ve ahlâklı veya ahlâksızca bir davranış, kişinin bu eylemi neden yaptığı konusuna ve düşüncesine göre de değişir..."

“...Evrensel ahlâk yasası mümkündür. Her yerde nerede olursan ol, kasten birini öldürürsen suç işlemiş olursun. Bence ahlâk yasalarının kaynağı dindir. Bir milletin dinî ne kadar gerçekse ahlâk yasaları da o kadar tutarlidır..."

“...Bence mümkün değildir. Çünkü toplumdan topluma, kültür farklılıkları vardır. Örneğin Rusya'da erkek erkeğe öpüşme normal kabul edilirken bizim kültürümüzde bu ahlâk dışı bir davranıştır. Evrensel ahlâk yasasında dinlerin çok büyük bir payı vardır. Dinlerde olan farklılıklar insanın ahlâkında da farklılık meydana getirir..."

“...Hayır mümkün değildir. Çünkü bizce ahlâklı görünen bir davranış, Almanya'daki bir insana ahlâksızlık olarak gelir. Her milletin kendi örf-adet ve ahlâk kavramları vardır. Yabancılarda gayet normal olarak karşılanan bazı davranışlar bizim dinîmize göre günah sayılıyor. Buna göre evrensel ahlâk yasası mümkün değildir..."

“...Bence mümkündür. İnsanoğlunu yaradan Allah olduğuna göre insanoğlunun doğruyu ve yanıı̧̧ı birbirinden ayırt etmesi ve mutlu yaşaması için evrensel ahlâk yasaları koymuş̧ur..."

“...Mümkün değildir. Çünkü ahlâk kuramları görecelidir. Bir durum karşısında herkesin tavrı durumu farklı olacağından Ahlâk yasası evrensel değildir. Büyük topluluklar için din birleştirici olabilir ama evrensellik yoktur..."

\section{7. Öğrencilerin Cevaplarının Oluşumuna Etki Eden Faktörler}

Ögrencilerin felsefe öğretiminde ön plana çıkan soruların cevaplandırılmasında ulaştıkları sonuçlara etki eden faktörleri belirlemek amacıyla "Yukarıdaki sorulara ilişkin olarak düşüncelerinizin oluşumuna etki eden faktörleri yoğunluk derecesine göre sıralayınız" şeklinde bir soru sorduk. Sunmuş olduğumuz seçenekler şunlardı:

- Anne-Baba, Cami-İmam, Din Kültürü ve Ahlâk Bilgisi Dersleri, Felsefe Dersleri, Okumuş Olduguum Kitaplar, Diğer Etkenler.

Ögrencilerin bunları etkenlik derecesine göre sıralamasını istedik. Öğrenciler en fazla etkili olduğunu düşündükleri faktöre 5 puan vererek, diğerlerine de azalarak puanlama yapacaklardı. Şimdi her bir faktörün öğrenciler tarafından nasıl değerlendirildiğini inceleyelim.

a. Anne-Baba

(5). $34,(4) .21,(3) .8,(2) .6,(1) .4$

b. Cami-İmam

(5). $11,(4) .6,(3) .21,(2) .4,(1) .10$

c. Din Kültürü ve Ahlâk Bilgisi Dersleri 
(5). $25,(4) .16,(3) .16,(2) .16,(1) .6$

4. Felsefe Dersleri

(5). $36,(4) .17,(3) .8,(2) .5,(1) .15$

5. Kitaplar

(5). $25,(4) .21,(3) .10,(2) .11,(1) .7$

6. Çevre

(5). 1, (4). -, (3). 1,(2). -, (1). 1

Ögrencilerin, görüşlerini şekillendiren faktörlerden Felsefe dersleri ve anne-babalardan almış oldukları bilgiler belirgin bir şekilde ön plana çıkarken DKAB dersleri de onlara yakın bir sayıda öğrenci tarafından önemli bulunmaktadır. Cami-imam kaynaklı bilgiler ise en arkada yer almaktadır. Bununla birlikte sayıların bir birine yakınlığı ciddî bir yorum yapılmasının önünde bir engel teşkil etmektedir. Ayrıca araştırmanın felsefe öğretimi süreci içinde gerçekleştirilmiş olması da felsefe derslerinin ön plana çımmasına bir neden teşkil etmiştir.

\section{8. Öğrencilerin Düşüncelerinin Oluşumuna Etki Eden Kitapların} İsim ve Yazarları

Önceki sorumuzda düşüncelerin etkilenmesinde önemli bir faktör olarak karşımıza çıkan "kitaplann" öğrenilmesine yönelik olarak sorduğumuz soruya verilen cevaplar çok uzun bir kitap listesi karşımıza çıkardı. Ben buraya sadece üzerlerinde uzlaşı bulunanları aldım:

- Sefiller (V. Hugo) (10), - Sofinin Dünyası (12), Suç ve Ceza (Dostoyevski) (7), Bize Nasıl Kıydınız (E. Şenlikoğlu) (6), Yüreğinin Götürdüğ̈ Yere Git (S. Tamaro) (6), Risale-i Nur (5), Simyacı (4), Kapital (K. Marx) (3), Ídamlık Genç (E. Şenlikoğlu) (5), Kur'ân-ı Kerim Meali (5), Gençliğin Imanını Sorularla Çaldılar (E. Şenlikoğlu) (3), Bir Deliyle Evlendim (H. İsmail) (3)

Bu kitapların dışında 95 kitaplık bir okuma listesi karşıma çıktı. Ancak yukarıdakiler gibi bu kitaplar da çoğu aktüel olmak üzere çok okunan romanlardan oluşmaktadır. Öğrencilerin okudukları kitaplar içinde bizim sor-muş oldugumuz soruların cevaplarını etkileyecek kitaplar bunlar arasında çok az yer tutmaktadır. Bu sonuçlarda Bingöl ilinin kendine özgü sinırlılıkları bulunmakla birlikte, yine de lise öğrencilerinin düşüncelerin gelişimine etki edecek kitaplar yerine aktüel kitapları tercih ettikleri sonucuna ulaşabiliriz.

\section{E. Sonuç Ve Öneriler}

Ortaöğretimde Din Kültürü ve Ahlâk Bilgisi öğretimi ile Felsefe öğretimi arasındaki ilişkiyi sorguladığımız bu araştırmada ulaştığımız sonuçlar ve yapmış olduğumuz öneriler aşağıdaki gibi sıralanmıştır:

1. Din Kültürü ve Ahlâk Bilgisi öğretimi ile Felsefe ögretimi derslerin genel amaçları, konuların amaçları, hedef davranışlar ve içerikleri açısından birbirleriyle ilişki içindedir. Bu ilişki, söz konusu öğretim alanlarının aynı 
ögrenci gruplarına aynı dönemlerde yönelmesi nedeniyle daha fazla anlam kazanmakta ve ciddî bir şekilde incelenmesini gerektirmektedir. Felsefe öğretiminde hayatın anlamlandırılması sürecine katkı amacıyla ortaya konan soruların hemen tamamı dinler tarafından da cevaplandırılmaya çalışılan sorulardır. Felsefe derslerinin amaçlarında somutlaşan ve bu amaçlar çerçevesinde bağımsız üniteler şeklinde düzenlenen "bilgi, bilim, varlık, ahlâk ve din felsefesi" gibi alanlarda ortaya konan sorulara bilinen ilk filozoflarla birlikte dinlerin de verdiği cevaplar bulunmaktadır.

2. Bu iki disiplin arasındaki sıkı ilişkiye rağmen, felsefe öğretimi kendisi için belirlenen "felsefi düşünme becerisini geliştirebilme" amacını da göz ardı ederek sorulan sorulara dinîn verdiği cevapları görmezden gelmiş; dine söylemediklerini yüklemiş; Hristiyan teolojisi ile felsefe arasındaki tarihsel ilişki genellenerek din-felsefe ilişkisinin tümü hakkında sonuçlar üretilmiştir. Bunun sonucu olarak da ciddi yanlış anlamalara sebep olunmuştur. Dinsel bilgi-felsefi bilgi ayırımında, din-siyaset ilişkisinde ve ahlâk felsefesinde bu hatalı genelleme sonucu oluşan yanlış bilgilendirmeleri gözlemlemek mümkündür.

3. Orta öğretim aşamasındaki Din Kültürü ve Ahlâk Bilgisi öğretimi, felsefenin sormuş olduğu sorulara sistematik bir biçimde cevaplandırma kaygısıyla düzenlenmemiştir. Bunun sonucu olarak da felsefenin sorularının önemli bir kısmı program dışında kalmıs, cevap bulunanlarda ise tatmin edici bir derinlik sağlanamamıştır.

4. Ortaöğretim sürecinde bulunan ögrenciler, bu iki alanın birbirini görmezden gelen tutumu sonucunda her iki alan öğretiminden de yeterince yararlanamamakta ve hayatın anlamlandırılması sürecinde gereken katkı sağlanamamaktadır. Öğrencilerden elde edilen bulgulara baktığımız zaman bilimsel bilgi, dinsel bilgi ayırımının felsefe öğretimindeki duruşa göre temellendirilmesine rağmen, doğru bilginin ölçüsü konusunda önemli oranda dinsel referanslara dayanıldığı gözlenmektedir. Yine varlı̆̆ın kökeni konusunda dinsel referanslar en başta sunulmaktadır. Tanrının varlığı, kanıtlanabilir olgulardan kabul edilmektedir. Öğrenciler üzerinde yapmış olduğumuz gözlemler de felsefe öğretimi ve din kültürü ahlâk bilgisi öğretiminin bir tercih yapılması gereken iki farklı bilgi türü sunduğu gibi bir düşüncenin oluştuğunu göstermektedir.

5. Öğrencilerin felsefenin sormuş olduğu sorular karşısında cevaplarının oluşumuna ögretim dışı faktörler daha fazla etkili olmaktadır. Aile, çevredeki ibadethane ve okudukları ders dışı kaynaklardan elde edilen bilgiler, öğrenciler üzerinde felsefe ve din kültürü ve ahlâk bilgisi öğretiminin sunduğu bilgilerden daha fazla etkilidir.

6. Araştırmadan elde edilen bu bulgular çerçevesinde felsefe öğretiminin, felsefenin soruları kapsamında dinîn cevaplarını da ideolojik bir duruşun ötesinde gerçek bir felsefî duruşla yansız ve doğru bir biçimde verecek şekilde yeniden düzenlenmesi gerektiği sonucuna ulaşılmıştır. Dinîn cevapları verilirken dinlerin genel bakış açılarıyla farklılaştıkları noktalar ayırt 
edilmelidir. Hristiyan teolojisi ile felsefe arasındaki gerilimli ve tartışmalı sürecin tüm dinler bağlaınında genelleştirilmesi yanlışından uzak durulmalidir.

7. Din Kültürü ve Ahlâk Bilgisi öğretiminin de felsefenin sormuş olduğu soruları temel alarak yeniden düzenlenmesi gerekmektedir. Felsefenin soruları, aynı zamanda insanın varoluşunu belirleyen temel nitelikteki sorulardır. Bunlar insanlığın düşünce birikimini oluşturmaya başladığı ilk zamanlarla birlikte sorulmuş, cevapları aranmış ve hâlen mutlak sonuçlara ulaşılmış da değildir. Hayatın anlamlandırılması sürecine katkı sağlama amacındaki bir öğretim alanının bu soruları görmezden gelmesi düşünülemez. Bu açıdan İlahîyat disiplini içinde çeşitli alanların, bu sorulan temel alan çalışmalara özellikle yönelmesi ve ortaya konan birikimin de orta öğretim din kültürü öğretimine uygun bir biçimde aktarılması gerekmektedir.

8. Bu araştırma sonucunda ortaya koyduğumuz bir diğer öneri ise öğrencilerin felsefi düşünme becerilerini daha iyi geliştirebilmeleri için felsefe ögretiminin daha önceki aşamalardan başlatılmasıdır. Bu şekilde ögrenciler insanın varoluşsal sorularını daha iyi öğrenebilecekler, bunları değerlendirebilecek ve özgün fikirler ekleyebileceklerdir. 